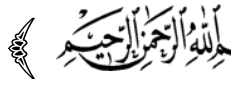

䍃

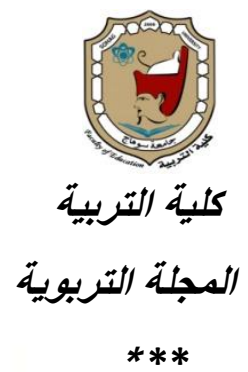

هبانية التعليم الجاهمى وملاقتها بتكافؤ الفرص التهليمية

فى ضوى التصديات الراهنة وأزهة التصول"

$$
\begin{aligned}
& \text { إعداد } \\
& \text { د/ أسماء أحمد خلف حسن } \\
& \text { جامعة سوهاج - وحدة التخطيط } \\
& \text { الاستراتيجى }
\end{aligned}
$$

المجلة التربوية ـ العدد التاسع والخمسوز ـ مارس 19 ا•rم

Print:(ISSN 1687-2649) Online:(ISSN 2536-9091) 


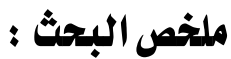

إن للجامعات دور بارز ومهم في مختلف جواتب الحياة وميادينها لافع الدول النامية

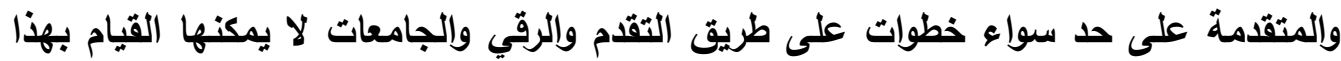
الدور على الوجه المطلوب إلا إذا اهتمت بتحقيق مبدأ تكافؤ الفرص في التعليم ، كما أنه أدى الأخذ بسياسة الباب المفتوح بالتعليم الجامعى وتقرير مجانيته إلى زيادةٌ إقبال الراغبين

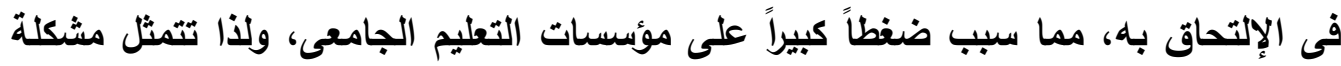

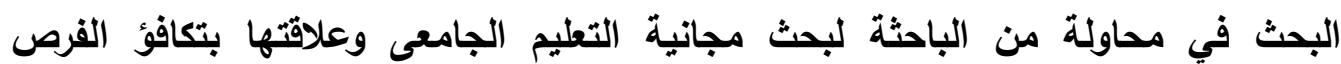

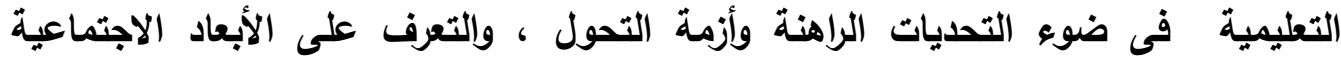

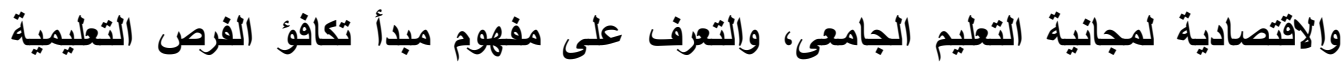

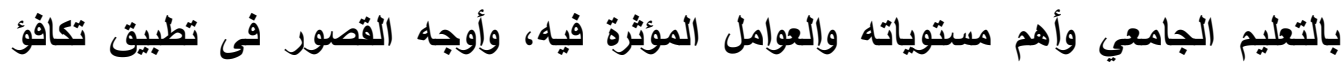

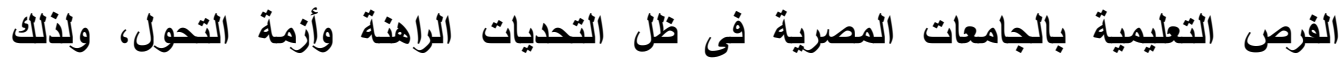

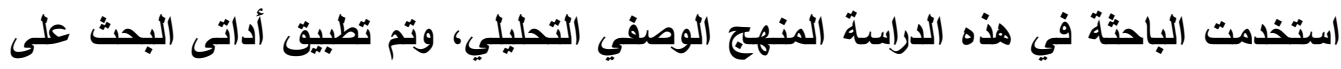

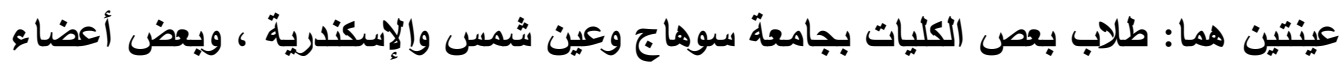

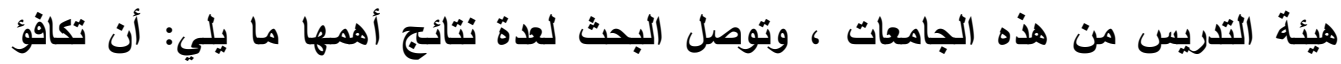

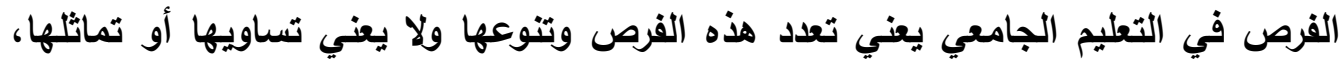

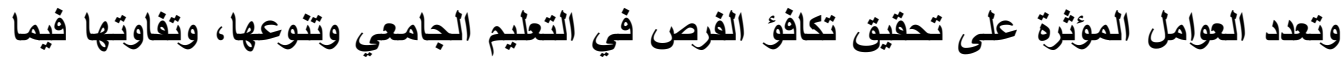

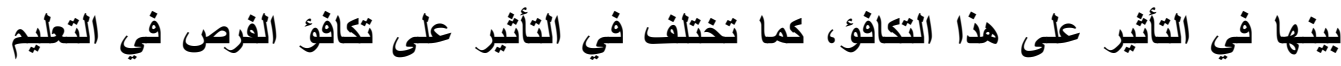

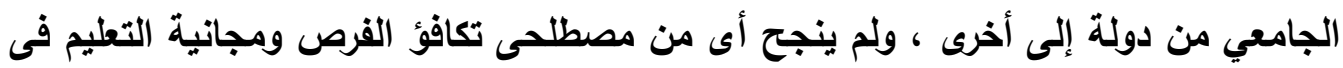

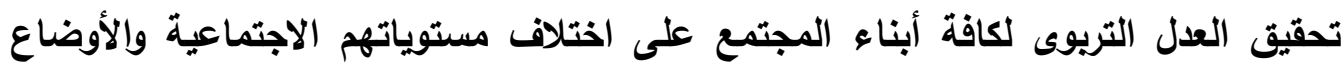

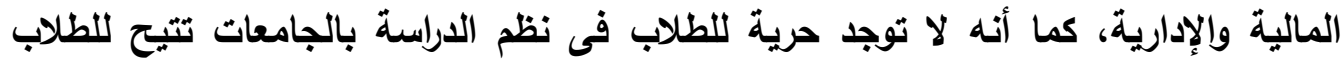

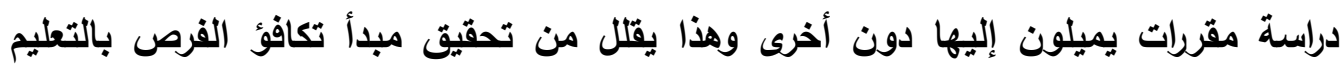

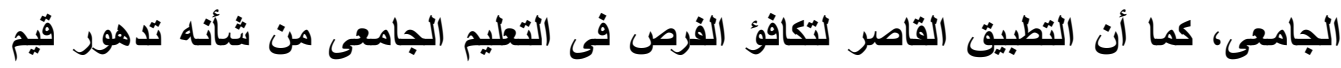

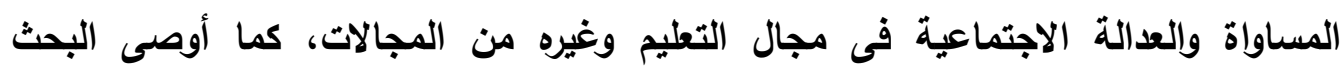

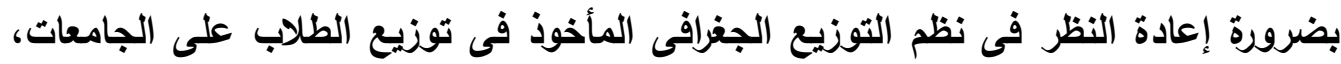

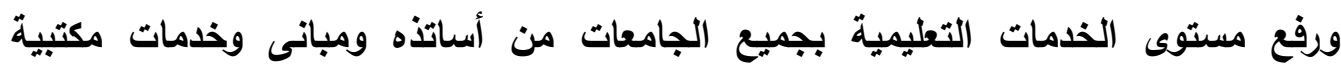
ويحثية، والإهتمام بالطلاب المتفوقين وتقيمي التسهيلات المادية التى تساعدهم فى مواصلة

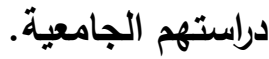


مقلدمة :

إن للجامعات دوراً بارزاً ومهم في مختلف جوانب الحياة وميادينها لافع الدول النامية والمتقدمة على حد سواء خطوات على طريق التقدم والرقي والجامعات لا يمكنها القيام بهذا الدور على الوجه المطلوب إلا إذا اهتمت بتحقيق مبدأ تكافؤ الفرص في التعليم ، كما أنه أدى الأخذ بسياسة الباب المفتوح بالتعليم الجامعى وتقرير مجانيته إلى زيادةٌ إقبال الراغبين

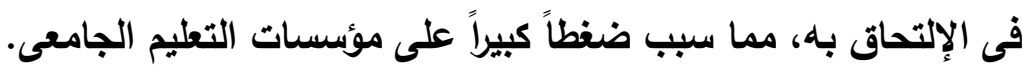
ومجانية التعليم ليست مجرد حق دستوري ناضل من أجله الإنسان عموماً، بل هي الإني

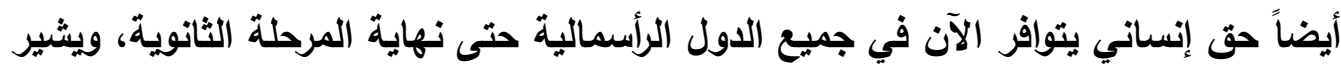

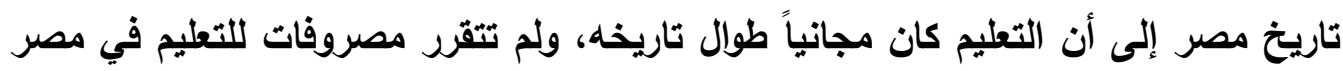

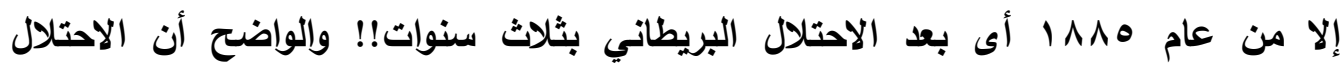
البريطاني تعدد إحداث تغييرات جذرية في تركيبة المجتمع المصري منها إقرار المصروفات

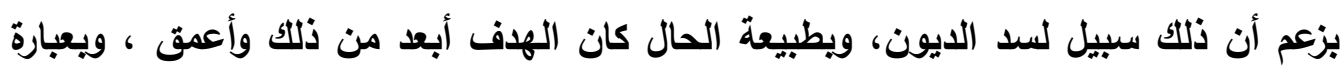
أوضح كان أخبث من ذلك، ويستهذف إجراء إنتقاء معين لتوعية المتعلمين بناء على الفئة

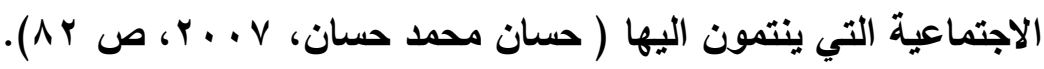
وفي عام r 9 r 19 تحققت مجانية التعليم الجامعي بعد قرارات التحول الإثتراكى، ومن هنا فإن قرارات المجانية ارتبطت بقوى اقتصادية واجتماعية وسياسية استهدفت تحقيق انجازات وطنية وثقافية، ونفس الثئ فإن قرارات فرض المصاريف ارتبطت بقوى معاكسة ( حسان

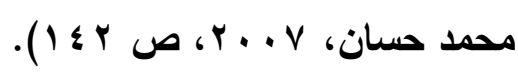
ومبدأ تكافؤ الفرص التعليمية يسعى إلى تحقيق العدالة عن طريق التنافس على المنافع المنشودة، ومن ثم يجب إزالة العقبات التي تحول دون ذلك، كما يجب أن تكون المنافسة وفقاً

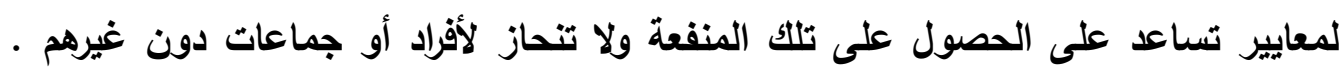

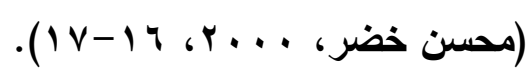
وتكافؤ الفرص التعليمية لا يعني فقط المساواة في حق التعليم لكل الأفراد بل يعني المساواة في الفرص التي تمكن الطالب من النجاح والتخرج، فتكافؤ الفرص في التعليم يتضمن بالإضافة إلى التكافؤ في فرص القبول والالتحاق، وتكافؤ في فرص الاستمرار فيه والنجاح والتحصيل والاستمرارية به حتى بعد التخرج. (جمال الدهشان، ه 1 • ب، ص 9 9). 
ولقد اهتم عديد من الدراسات بقضية تكافؤ الفرص التعليمية في مصر منها دراسة

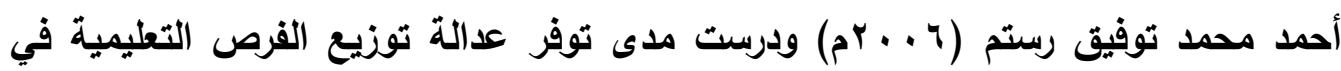
التعليم العام قبل الجامعي في مصر، وذلك من خلال عدة مؤثرات لتلك العدالة وأوضحت الفروقات الثديدة بتلك المراحل التعليمية التي تخل بمبدأ عدالة توزيع الفرص التعليمية.

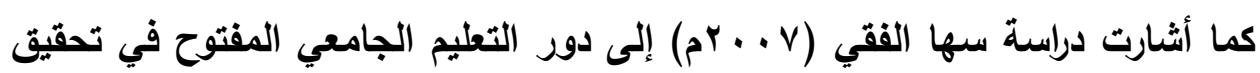
تكافؤ الفرص التعليمية في مصر وذلك لأنه يسهم في إعطاء فرصة لمن فاتهم قطار التعليم

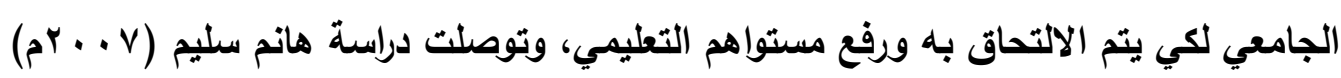
تصور مستقبلي لدور التعليم الإكتروني في تحقيق تكافؤ الفرص التعليمية في التعليم العام في مصر ووضعت الدراسة ذلك التصور المستقبلي باستخدام أسلوب دلفي والسيناريوهات.

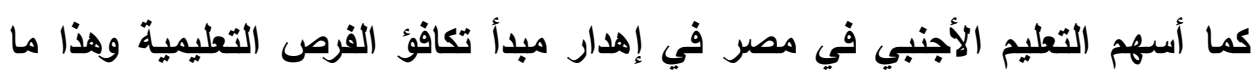
أكدته دراسة شيماء الحبشي (11 ـ بم)، حيث قامت الباحثة بعمل دراسة تحليلية تقويمية للتعليم الأجنبي في مصر وأثره على تكافؤ الفرص التعليمية.

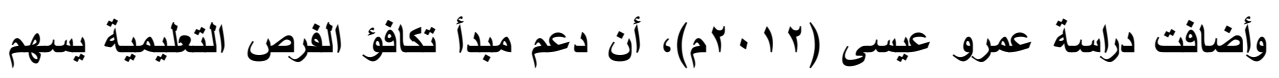

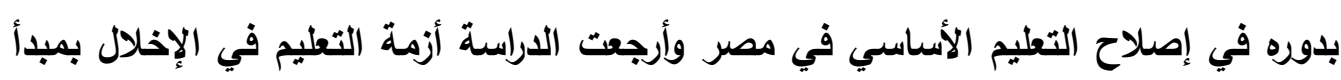

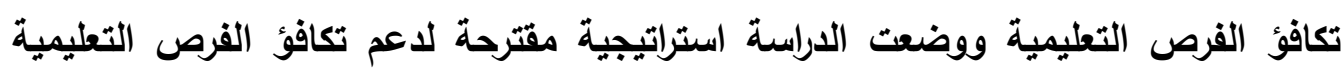

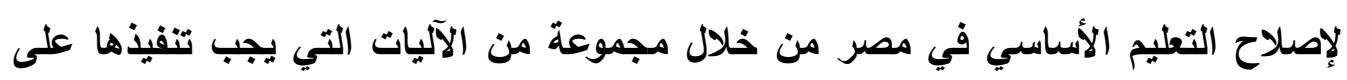

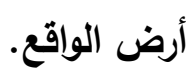

وفي دراسة بولاية كنتاكي (Knoeppel, R. \& Brewer, C, 2011 ) توصلت إلى أن المدارس التي تقع بالمناطق الثرية والغتية التي تمتلك الثروات المحلية يرتفع بها تحصيل

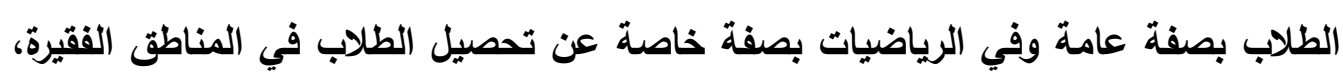
وذلك يرجع إلى أن تلك المدارس تتميز بامتلاك الإمكانات المادية والتجهيزات بشكل أكبر وأفضل من تلك المناطق الفقيرة، وكذلك المدرسون ذوي الخبرة يكونون بمدارس المناطق ذات الثروة المحلية العالية أما مدارس المناطق الفقيرة فيذهب إليها المعلمون غير المؤهلين والأقل

ويالرغم من الاهتمام بمبدأ تكافؤ الفرص في العملية التعليمية بالتعليم الجامعى في مصر ودعوة العلماء المستمرة للعمل على تطبيه إلا أنه يوجد إخلال شديد بهذا المبله المبأ وتوجد 
فجوات متعددة في فرص التعليم بين الريف والحضر وبين الأكور والإناث ويبن الطبقات الاجتماعية .

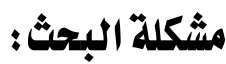

لقد كاتت خطورة ترويج فكرة أن التعليم وحده هو أداة التتمية تكمن في تغافل الدول

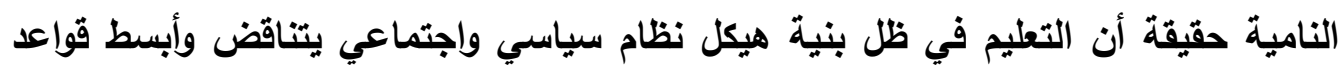

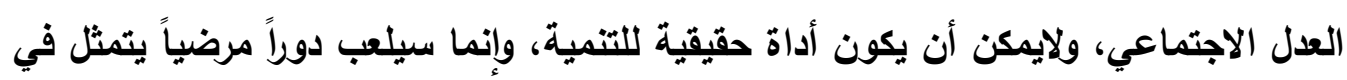
إعادة إنتاج المقومات والأركان التي تديم استمرار الظلم الاجتماعي وخلل نست القيم.

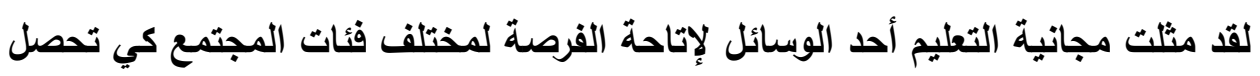

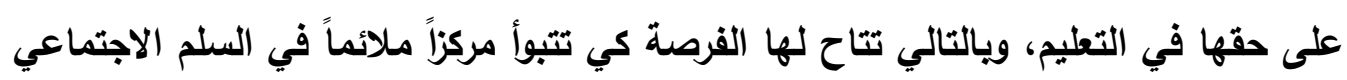
تعتمد فيه على مالديها من كفاعة. إلا أن القوى الأخرى سرعان ما استتلت ضعف الماله الموارد المالية للاولة نتيجة ظروف عديدة، وعجزها بالتالي عن ملاحقة مما يتطلبه تزايد الطلب الاجتماعي من مزيد من الإنفاق

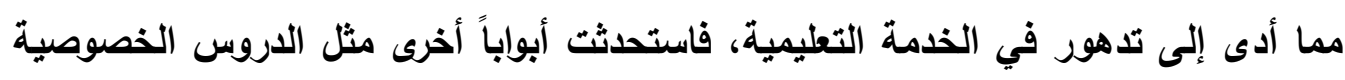
ومدارس اللغات لتقدم خدمة تعليمية أحسن لمن يدفع أكثر، ويدأت بالتالي عملية إعادة فرز

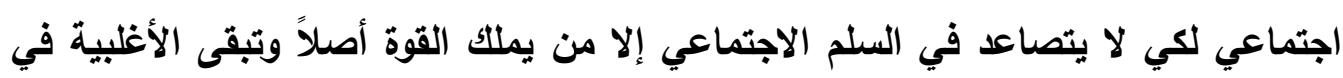

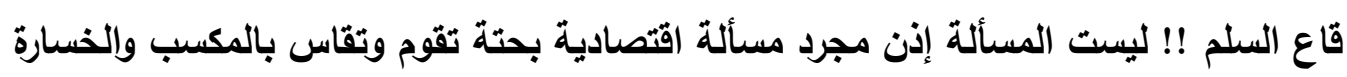
الماليين، كما أنها ليست مجرد مسألة بيداجوجية تتحكم فيها فنيات التدريس والتعليم. وإن علم الاقتصاد منذ نشأ منذ مائتي عام، لم يخف على أحد أن أية سياسة اقتصادية تعكس مجموعة من المصالح، وأن مصالح الناس والدول متضارية وأن الاختيار بين

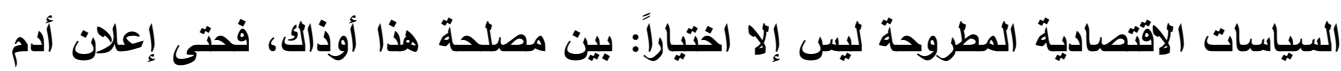

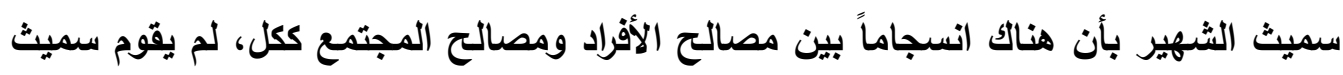

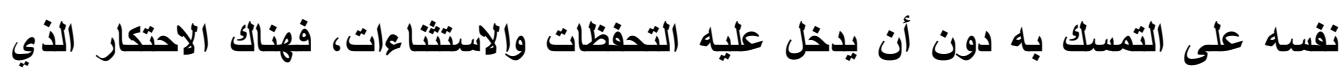

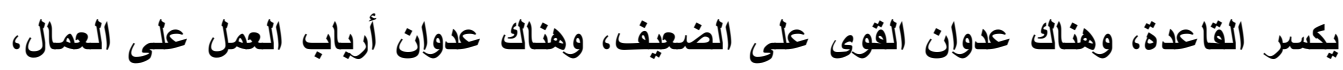

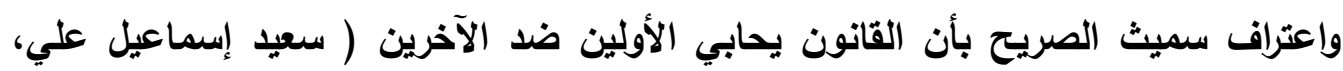

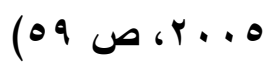


ومنذ أن وجد مجتمع إنسانى على ظهر الأرض والتمسك بإبقاء كل شئ على ماهو عليه ورفض التفيير لا يأتي إلا من القوى المستفيدة من الوضع القائم. ومنذ أن نشأ علم من الأن العلوم الاجتماعية، فإن الذين يميلون إلى تصوير المشكثة الاجتماعية، والمثال هنا (مجانية

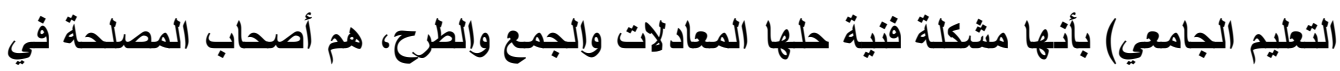
إبقاء كل شئ على ماهو عليه ذلك لسبب بسيط أيضاً، وهو أن القرارات الأساسية في حياة المجتمع لا تتخذ أبداً في يوم من الأيام بناء على عملية حسابية، بل بناء على تفضيل

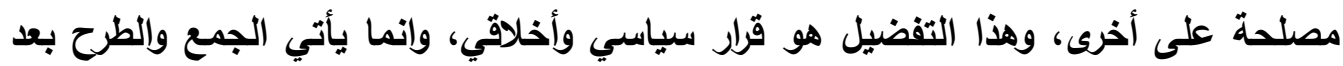

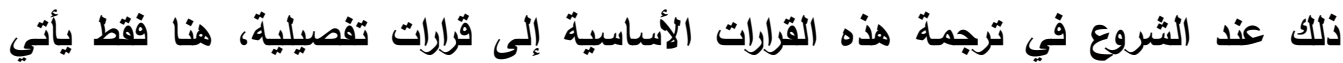
دورالخبرة ويبدأ حل المعادلات، فاذا لجأت السلطة السياسية إلى الخبراء وإلفنيين المفتقرين إلى أية روئة سياسية اجتماعية، أو الذين يتظاهرون بتجردهم من السياسة والاجتماع وظنت أن حل مشاكل التعليم سوف يتم على أيديهم، فلن تكون النتيجة للأسف إلا استمرار المشكلة، واستمرار المشكلة يعني زيادة تفاقسها وتفريح عدد آخر من المشكلات المتصلة بها.

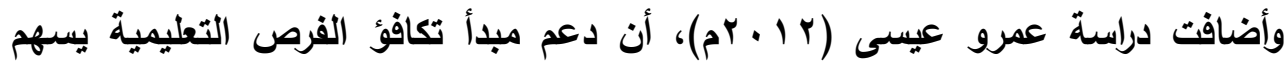
بلوره في إصلاح التعليم الأساسي في مصر وأرجعت الدراسة أزمة التعليم في الإخلال بمبدأ تكافؤ الفرص التعليمية . ونظراً لأهمية مبدأ تكافؤ الفرص في التعليم وأنه بدأ الإخلال به بشكل كبير فقد تزايدت

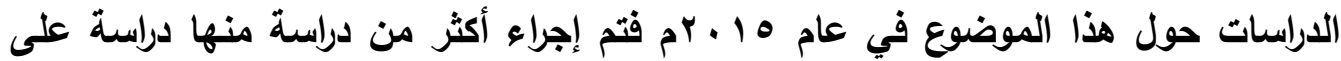
عبدالعزيز علي (10 ب rم)، وقام فيها بعمل دراسة تقويمية لبعض المدارس التجريبية في ضوء مبدأ تكافؤ الفرص التعليمية وحاول التعرف على نقاط القوة ونقاط الضعف بتلك المدارس ومدى تحقق مبدأ تكافؤ الفرص بها ثم وضع آليات لعلاج القصور بتلك المدارس. وتطور التعليم الجامعي المعاصر في مصر وارتبط ارتباطاً وثيقاً بالمجتمع ونموه والتنير والتقدم الحاصل فيه وخاصة بنمو الصناعة فيه وحاجة ذلك إلى تخصصات جديدة في مختلف نواحي العلم والتكنولوجيا وحاجة ذلك إلى عقول مفكرة وعمالة مدربة ذات كفاءة عالية لصالح الإنتاج والتنمية وإتساع الخدمات في ميادين الصحة والتعليم والرعاية الاجتماعية وأرتبط معنى تكافؤ الفرص التعليمية في التعليم الجامعي بخدمة ذلك كله ويإعداد القوى البشرية اللازمة لمواجهة تلك الإلتزامات الاقتصادية والاجتماعية في الدولة المصرية. 
وتثير دراسة أحمد إبراهيم أحمد( • ( + )، إلى أن مجانية التعليم في الجامعة قد انتهت تماماً ففي ظل الإرتفاع المجنون في سعر الورق، وفي تكلقة الطباعة، ارتفع ثمن الكتب والمذكرات، ولهذا لا يدفع الطالب أقل من خمسمائة جنيه سنوياً ثمناً للكتب والمذكرات التي يحتاجها، ويخاصة أن المكتبات في الكليات تفتقر إلى الكتب والمراجع اللازمة للاراسة بسبب ضعف إمكاناتها المادية، فضلاً عن المشروعات البحثية التي تتطلب خامات ومواد تعليمية غير متوفرة بالكلية، تستنفذ طاقات المتعلمين، كما أنها تستنزف إمكاناتهم المادية. وفى دراسة (Noel, B, 2015) عن تكافؤ الفرص في أمريكا اللاتينية تم تصميم نموذج هو نموذج لايمرز لتكافؤ الفرص التعليمية لقياس مدى تحقيق تكافؤ الفرص التعليمية في أمريكا اللاتينية ويتضمن هذا النموذج خمس مستويات لتكافؤ الفرص التعليمية هي مستوى الالتحاق ويتطلب عدد كاف من المدارس والفصول المناسبة للطلاب، ومستوى الجودة ويقصد به أن تحقيق الاستفادة القصوى للأطفال من التعليم الرسمي، ومستوى الاستمرار في الدراسة ويتم به تثجيع الطلاب للوصول إلى رتب تعليمية عليا، ومستوى الفوائد التي تحققت والمقصود بها الفوائد والمهارات والمعرفة التي اكتسبها الخريجون والمطلوية بسوق العمل، ومستوى الفرص العياة المستقبلية وهي القدرة على الاستمرارية في الاراسات العليا وتلقى حصة متساوية في المنافع الاجتماعية والاقتصادية.

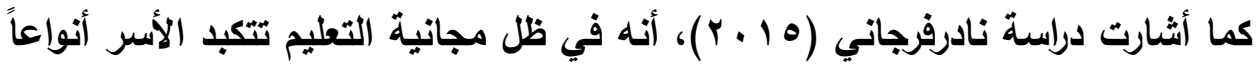
من التكلفة مثل بعض الرسومات وتكلفة الكتب والأدوات (ويخاصة في فروع العلوم التطبيقية والتقتية). ويساهم تزايد الفقر، في زيادة عبء هذه التكاليف بمرور الزمن وفي رفع تكلفة الفرصة البديلة للتعليم. وعلى هذا فإن انتثار الفقر يزيد باطراد من انتقائية التعليم العالي لهاي

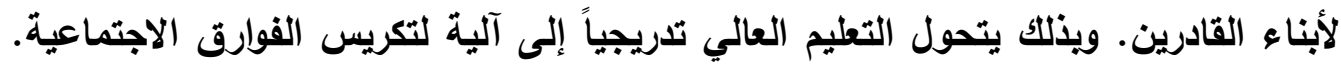

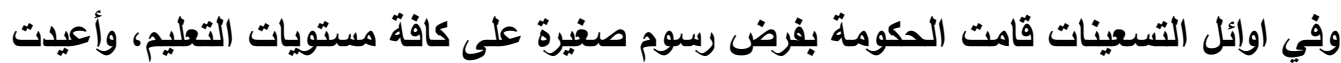
المصروفات في مستوى الدراسات العليا (دبلوم، ماجستير، دكتوراه)، إلا أنه لم يحدث مساس بمجانية التعليم على مستوى الدرجة الجامعية الأولى على هذا النحو، وأصبح التعليم سلعة داخل سوق يحكمه قانون العرض والطلب ولا يقدر عليه إلا فئة قليلة مع تنامي التعليم الخاص والأجنبي، وتعميم أقسام اللفات بالمصروفات في كل الكليات، ولا يزال الحديث عن التهن 


\section{مجانية التعليم الجامعى وعلاقتها بتكافؤ الفرص التعليمية فى ضوء التحديات الراهنة وأزمة التحول.}

المجانية وارداً ومتجدداً كلما اشتدت الأزمات والضغوط الاقتصادية ما بين مؤيد ومعارض، ولكل تفسيراته ومبرراته.

ولذا تتمثل مشكلة البحث في محاولة من الباحثة لبحث مجانية التعليم الجامعى وعلاقتها بتكافؤ الفرص التعليمية فى ضوء التحديات الراهنة وأزمة التحول.

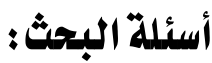
1. ما معايير تحقيق مبدأ تكافؤ الفرص التعليمية بالتعليم الجامعى فى ضوء التحديات الراهنة ؟ مات r. ما العوامل المؤثرة على مبأ تكافؤ الفرص التعليمية بالتعليم الجامعى فى ضوء التحديات الراهنة ؟ r. ما علاقة مجانية التعليم بتكافؤ الفرص التعليمية بالتعليم الجامعى ؟ ء. ما واقع مجانية التعليم الجامعى وعلاقتها بتكافؤ الفرص التعليمية فى ضوء التحديات الراهنة ؟

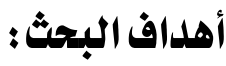
1. التعرف على معايير تحقيق مبدأ تكافؤ الفرص التعليمية بالتعليم الجامعى فى ضوء التحديات الراهنة. r. التعرف على العوامل المؤثرة على مبأ تكافؤ الفرص التعليمية بالتعليم الجامعى فى ضوء التحديات الراهنة . r. الكثف عن علاقة مجانية التعليم بتكافؤ الفرص التعليمية بالتعليم الجامعى . ء. الكشف عن واقع مجانية التعليم الجامعى وعلاقتها بتكافؤ الفرص التعليمية فى ضوء التحديات الراهنة. ه. التوصل إلى التوصيات المقترحة لتحقيق تكافؤ الفرص التعليمية بالتعليم فى ضوء التحديات الراهنة وأزمة التحول. أهمية البحثث : ترجع أهمية البحث إلى أنها تركز على موضوع هاماً وهو مجانية التعليم وعلاقتها بتكافؤ الفرص التعليمية وتتلخص أهمية البحث فى النقاط التالية : 


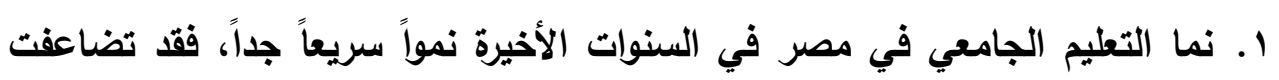

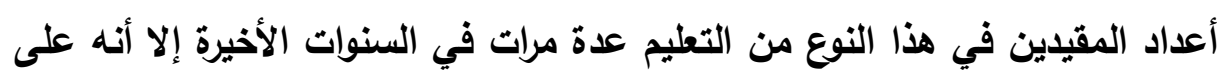

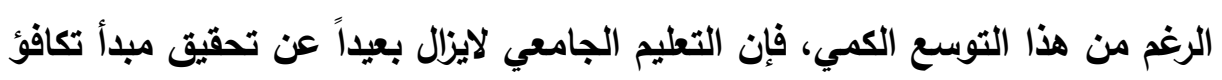

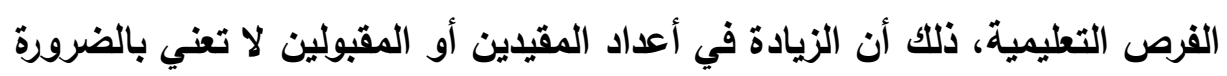

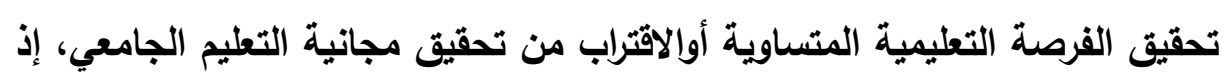

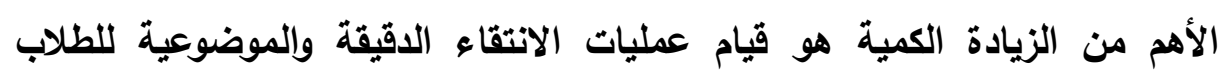
المتقدمين للالتحاق بالجامعة، وضمان السبل التي تيسر الاستفادة من الفرص التعليمية لمستحقيها فقط . r. الكثف عن قضية مجانية التعليم وعلاقتها بتكافؤ الفرص كخطوة أولى وأساسية نحو تعديل سير التعليم الجامعي والوصول به إلى تحقيق أهدافه، وهو ما تحاول الاراسة الحالية القيام به. r. يبين البحث للمسئولين عن التعليم الجامعى الى تأثير مجانية التعليم فى تحقيق به تكافؤ الفرص التعليمية للطلاب . ع. يبين البحث للمسئولين عن التعليم بصفة عامة والتعليم الجامعى بصفى خاصة أهم أوجه القصور فى أوجه القصوريمجانية التعليم الجامعى وعلاقتها بتكافؤ الفرص عن بهن التعليمية. منهج البجث : أبه: اعتمدت الدراسـة الحالية على المـنهج الوصفي لمناسبته لطبيعة الدراسـة، حيث تهتم البحوث الوصفية بظروف العلاقات القائمة والممارسـات الثـائعة والمعتقدات، ووجهات الماتهات النظر

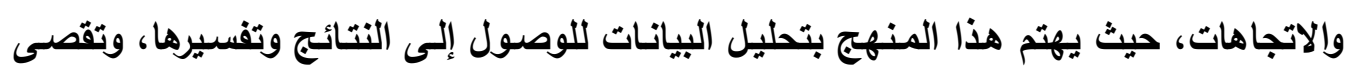
حول الظواهر المجتمعية والتريوية التعليمية، كما هي قائمة في الحاضر ووصفها وتثخيصها

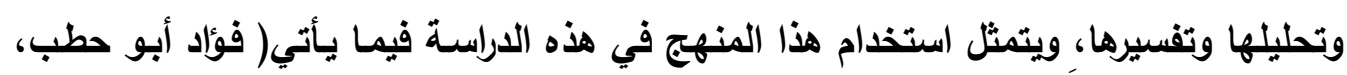

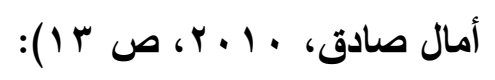
ا ـ جمـع الدراســات ذات الصـلة بالدراسـة الحاليـة، وتحليلهـا لمعرفـة واقـع مجانيـة التعلـيم الجامعى وعلاقتها بتكافؤ الفرص التعليمية فى ضوء التحديات الراهنة وأزمة التحول. 


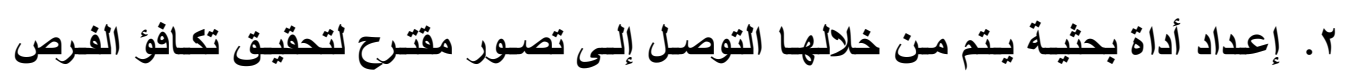

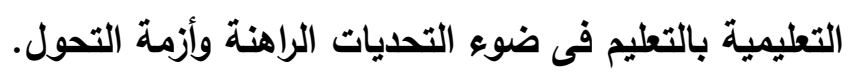

حدود البجثث :

الحدود الموضوعية : اقتصر البحث الحالى دراسة مجانية التعليم الجامعى وعلاقتها بتكافؤ الفرص التعليمية فى ضوء التحديات الراهنة وأزمة التحول الحدود المكانية : اقتصر البحث الحالى على بعض الكليات بجامعة سوهاج وعين شمس والإسكندرية ، ويعض أعضاء هيئة التدريس من هذه الجامعات .

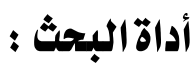
استخدمت الباحثة أداتى البحث على عينتين هما: طلاب بعض الكليات بجامعة سوهاج وعين شمس والإسكندرية ، ويعض أعضاء هيئة التدريس من هذه الجامعات.

مصطاحات البحث : مصن

Equality Of Educational Opportunities مبلأ تكافؤ الفرص التعليمية تعرف مبلأ تكافؤ الفرص التعليمية بالتعليم الجامعى بـأنها : ويقصد بتكافؤ الفرص : توفير فرص تعليمية متكافئة لتنمية قدرات واستعدادات ومواهب

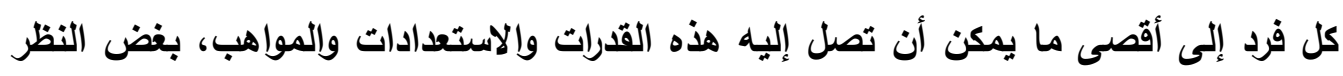

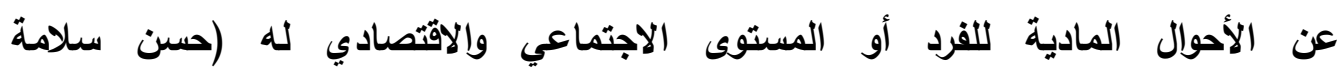

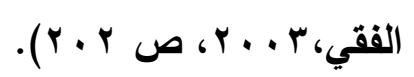

التعريف الإجرائى لتكافؤ الفرص التعليمية بالتعليم الجامى :العدالة فى إتاحة الفرص التعليمية للطلاب والطالبات للالتحاق بالتعليم الجامعى وأن يكون الالتحاق بالكليات المختلفة

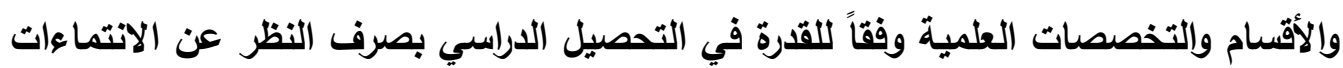

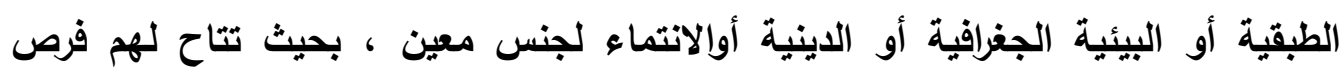

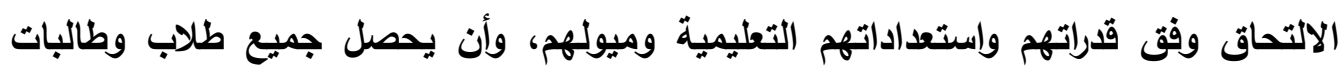

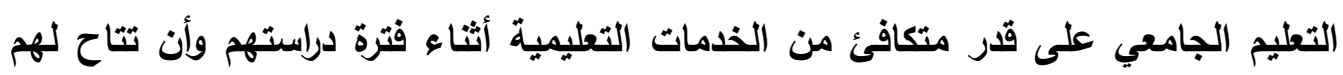

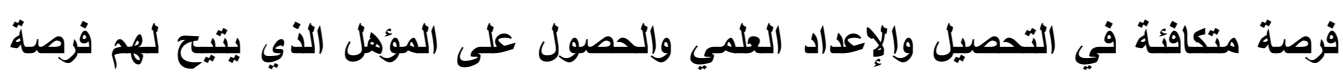
متكافئة في العصول على وظيفة في سوق العمل. 


\section{الإطار النظرى}

مقدمة :

مما لا شك فيه أن الانسان يعيش اليوم عصر التغيرات السريعة المتلاحقة. والتعليم أصبح

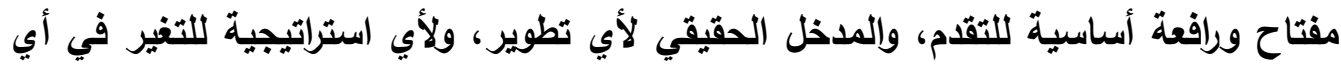
مجتمع، فلا يمكن أن تتم مثل هذه الإستراتيجية دونما اعتبار التعليم أحد آلياتها الأساسية، والمسائل الملحة التي تحتاج لحل جذري اليوم تكمن في معرفة الخطوات والإجراءات الواجب الإب التهات اتخاذها في ميدان التربية لإقامة علاقات من نوع جديد بين الأصل الاجتماعي والتربية والحياة، للتوصل لإتاحة الفرصة لكل فرد مهما كان أصلة الاجتماعي وانتماؤه الطبقي لإني للاستفادة بشكل متكافئ من التربية.

تعد اتفاقية اليونسكو بشأن مكافحة التمييز في مجال التعليم صكاً رئيسياً يتناول المبادئ لأئئ

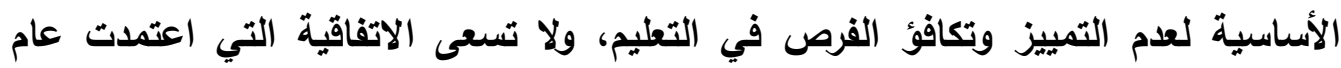

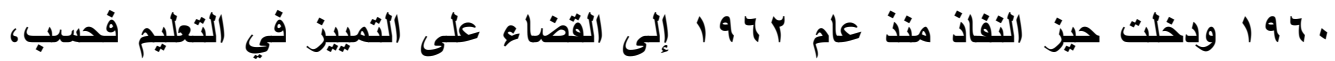
وإنما أيضاً إلى اعتماد تدابير إيجابية لتعزيز تكافؤ الفرص والمساواة في المعاملة وتبين

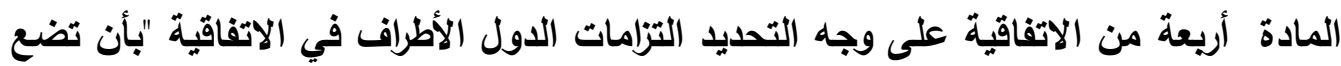
وتطور وتطبق سياسة وطنية تستهدف، عن طريق أساليب ملائمة للظروف والعرف السائد في البلاد، دعم تكافؤ الفرص والمساواة في المعاملة في أمور التعليم" (الأمم المتحدة، .$(r \cdot 1)$

وتتبع أهية التكافؤ في الفرص التعليمية بالتعليم الجامعى من ارتباطه بالتكافؤ في

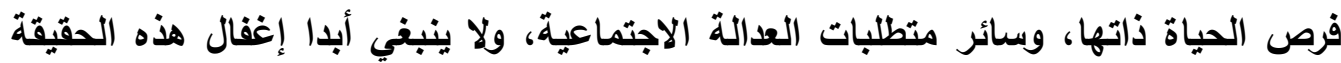

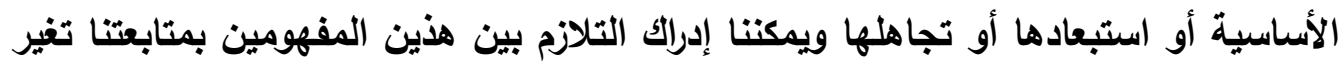
نمط الإنتاج وتطور الحياة الاجتماعية ونمط التعلم عبر التاريخ ولا سيما منذ قيام الثورة الصناعية. إذ برزت مسألة الحراك المهني، وما يرتبط بها من حرالك اجتماعي جغرافي سعيا نحو العمل والاشتغال بالمهن المستحدثة في المجتمع، إذن فمفهوم التكافؤ في الفرص التعليمية يرتبط بشدة بمفهوم التكافؤ في الفرص المهنية أ التوظيف ومن ثم فرص الحياة وكل فئل

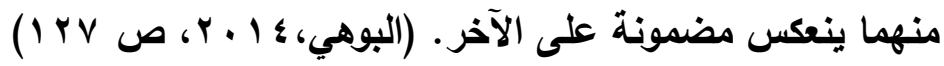


ويقصد بمبدأ تكافؤ الفرص توفير الشروط المتساوية والموحدة بين كافة مواطني البلد الواحد فيما تتيحه الدولة من فرص. ويقصد به في التعليم إتاحة الفرصة المتساوية أمام جميع الأطفال للالتحاق بالمدرسة قصد اكتساب المعارف و المهارات لتحمل المسؤوليات في لي لئ مجتمعهم ووطنهم. و يسعى مبدأ تكافؤ الفرص في ميدان التربية و التعليم إلى تعميم التعليم و الزاميته و مجانيته و تبني التقويم الموضوعي و العدل في المعاملة، و إعطاء فرص متساوية لكافة أبناء الوطن الواحد بغض النظر عن أصولهم الاجتماعية و الاقتصادية. (أحمد

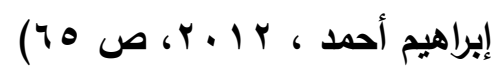
ويعد هذا المبأ أحد البوابات الرئيسة لتحقيق العدالة الاجتماعية، فتكافؤ الفرص "ليس

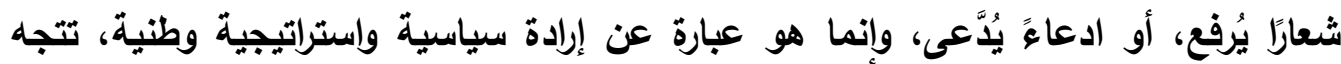
بصدق نحو إزالة كلّ المعوقات والعوامل التي تميّز بين المواطنين، وقد درج مصطلح تكافؤ الفرص على ارتباطه في الذهن - غالبا- بالفرص التعليمية والوظيفية - بالدرجة الأولى - رغم ارتباطه بجميع مناحي الحياة المختلفة التي يعيش فيها الفرد، وتعتبر من حقوقه مقابل واجباته تجاه نفسه والآخرين ثم وطنه، فهو معيار تقدم أي مجتمع في جميع مجالات الحياة.

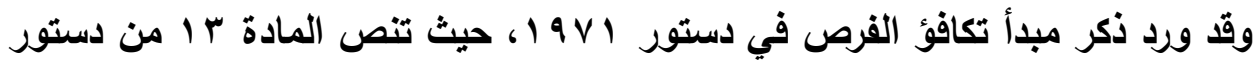
عام I9V1 أن العمل حق وواجب وشرف تضمنه الدولة ويجب أن تعمل الدولة والمجتمع على تقدير الموظفين المتميزين. كما تنص هذه المادة على عدم إرغام المواطنين على العمل إلا بموجب قانون يعلن أن العمل مطلوب لتقديم خدمة ويشرط أن يتم هذا العمل مقابل تعويض عادل. وهذا الحكم يعطي جميع المواطنين حقا دستوريا في العمل دون التفرقة بين الرجل والمرأة، و" تضمن الدولة تكافؤ الفرص لجميع المواطنين"، والمواطنون متساوون أمام القانون ، ولهم حقوق وواجبات متساوية دون تفرقة بسبب الجنس ، الأصل ، اللغة ، الدين

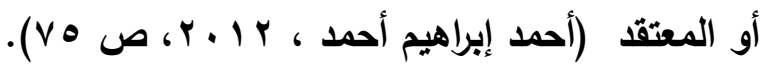


أولاً : مفهوم تكافؤ الفرص التعليمية بالتعليم الجامعى :

قد تعددت مفاهيم تكافؤ الفرص لأنه "مفهوم معقد وغير محدد، وهو مفهوم افتراضي

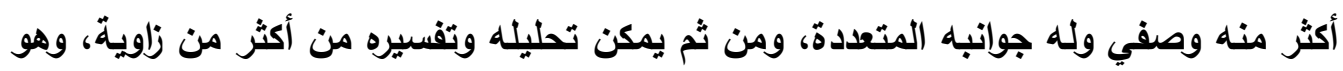
من المفاهيم التي تتغير تفسيراتها من مجتمع لأخر، وفي نفس المجتمع من فترة زمنية لأخرى

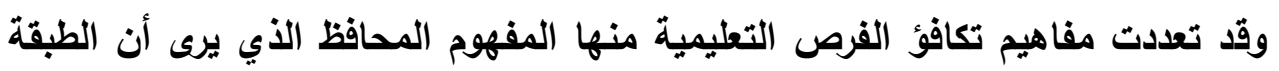
الاجتماعية هي المحدد لقدرات الفرد ويذلك يكون أصحاب المواهب والقدرات ممن ينتمون للطبقات الراقية وهم الأجلر بالفرص التعليمية، والمفهوم الليبرالي يعني بمنح الفرد الفرصة

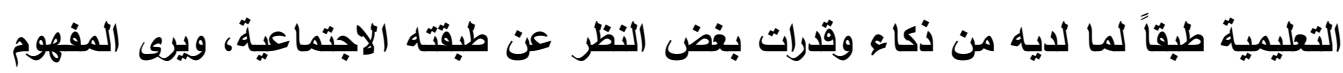
الراديكالي أنه لابد من نشر المساواة بين الأفراد ليس فقط بلخول الافراد المؤسسات التعليمية ولكن بتحييل آثار العوامل الاقتصادية والاجتماعية في التحصيل والدراسة(علي

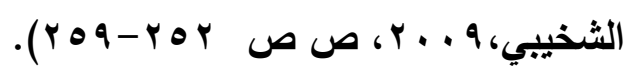

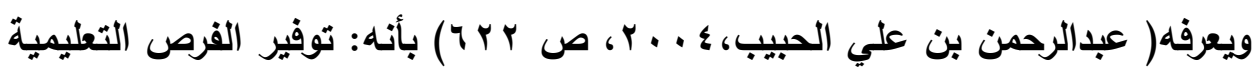

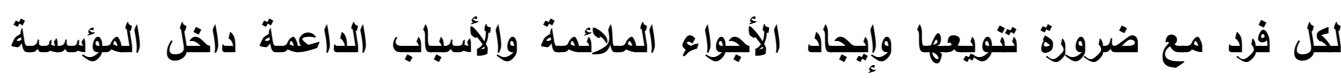
التعليمية، والتي تمكن كل فرد من الاستفادة من هذه الفرص المتكافئة في تنمية قدراته واستعداداته ومواهبه إلى أقصى حد يمكن أن تصل إليه، مهما كانت خلفيته الاجتماعية وأوضاعه الاقتصادية، وما يرتبط بهذه الخلفية وتتلك الأوضاع من عوامل نفسية وأكاديمية.

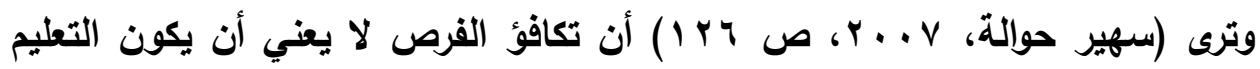

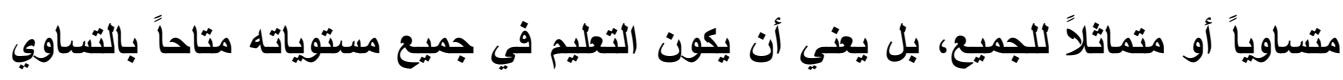

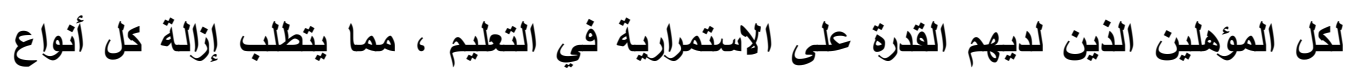
التمييز الأخرى.

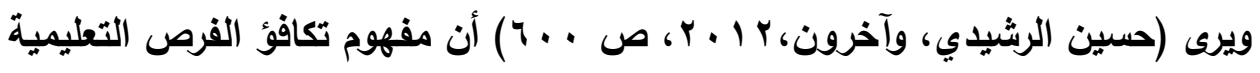

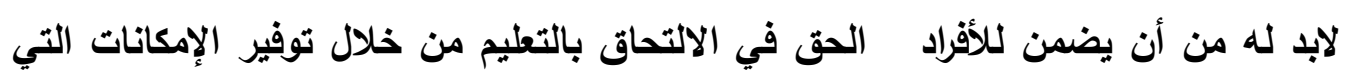
تسير الاستفادة الكاملة من الفرص التعليمية، والمساواة في مواصلة الفرد للتعليم والاستمرارية فيه بما يتناسب مع قدراته واستعداداته وإحتياجاته.

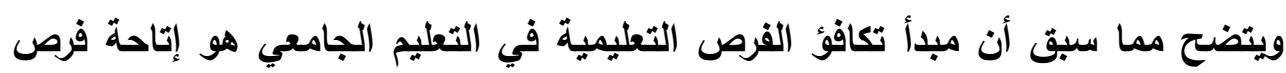
متكافئة للطلاب والطالبات للالتحاق به وفقاً للقدرة في التحصيل الدراسي بصرف النظر عن فئن 
الانتماءات الطقية أوالبيئية الجغرافية أو الدينية او الانتماء لجنس معين أي مراعاة الفروق فئيق

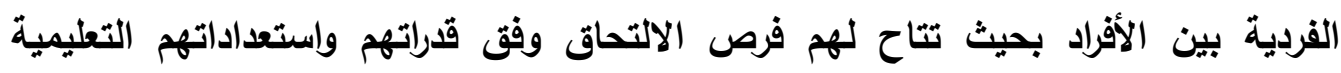

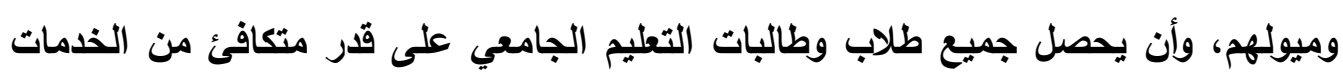
التعليمية و وميونم،

ثانياً : معايير تحقيق مبدأ تكافؤ الفرص التعليمية بـالتعليم الجامعى فى ضوء التحديات الراهنة : يحدد هنري، م. ليفين. من خلال دراسة أجراها لحوالي عشرين بلاً غربي أوربا لتحليل

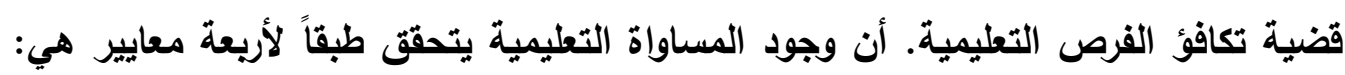

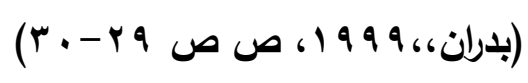

1. المساواة في الإلتحاق بالتعليم: يستتد هذا المعيار كما يري كولمان إلي إمداد تعليم مجاني في مستوى معلوم يكون نقطة الاخول الأساسية لقوة العمل.

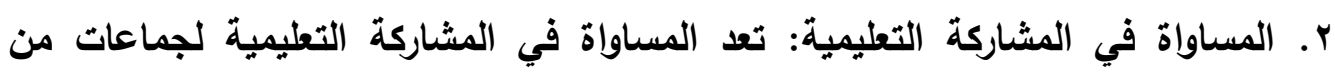
أصول اجتماعية متباينة واحد من معايير المساواة في الفرص التعليمية، ويمكن روئيتها

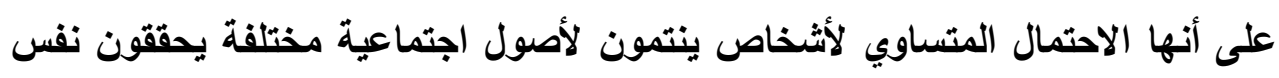

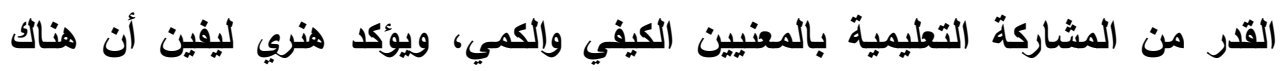

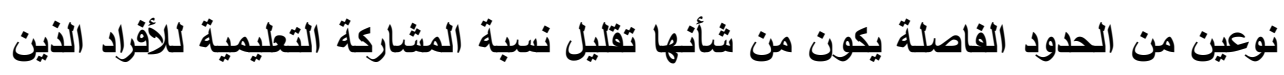
ينتمون إلى لطبقات اجتماعية متباينة وهذه الحدود هي: حدد فاصلة خارجية عن الجامعة ترتبط بالأسرة، و حدود فاصلة ترتبط بالبناء الجامعى. وتتضمن الحدود الأولى ولى الجى

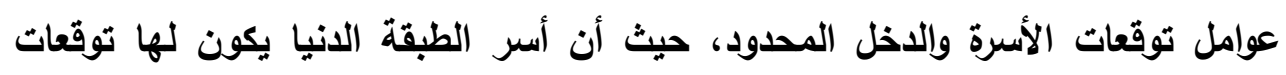

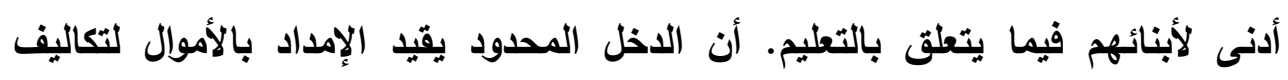
•التعليم. r. المساواة في النتائج التعليمية: وهو يعني أن الاعضاء الذين يمثلون الطبقات الاجتماعية

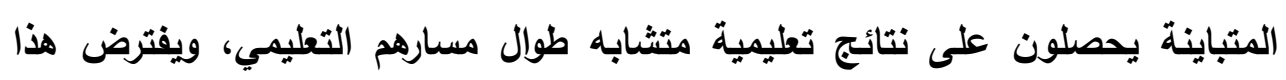
المستوى أن تحقيق المساواة في الفرص التعليمية لا يتم من خلال قدر من التعليم الذي فئي يحصل علية الفرد وإنما تظهر في إمداده بالمهارات والسلوكيات والاتجاهات التي تسهر لتهن في إيجاد شباب منتج، والواقع أن المساواة في النتائج ارتبطت بموضوع التجاح التملئ والتيمي. 
والعوامل المؤثرة فيه مثل اهتمام الوالدين بالتعليم. التاريخي التعليمي للأسرة والطموح المهني للأطفال ودرجة الأمن في الأسرة ونوعية الجامعات وجودتها.

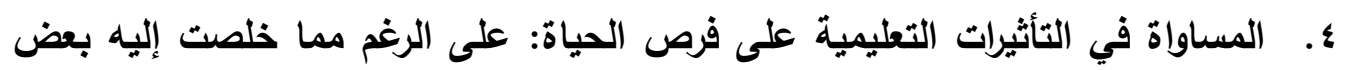
الاراسات من أن التأثيرات التعليمية كان لها علاقة طفيفة بتوزيع الدخل، إلا أن الدراسات

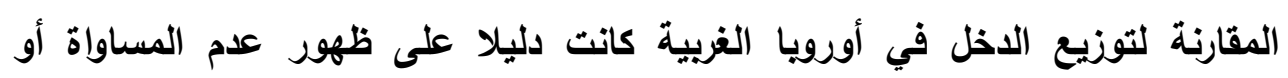
الاستقرار النسبي لتوزيع الاخل مع عدم وجود اتجاه نحو مساواة أكثر. فلقد وجد العالم (جنكز) وعدد من الباحثين أن هذا لم يتحقق، حيث ظل أبناء الطبقة العليا هم الأفضل

$$
\text { ويستأثرون بالمهن. }
$$

ثالثاً: العوامل المؤثرة فى تحقيق تكافؤ الفرص التعليمية بالتعليم الجامعى فى ضوء التحديات

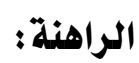

إن موقف التعليم الجامعي من تحقيق مبدأ تكافؤ الفرص التعليمية تختلف حوله الآراء بين

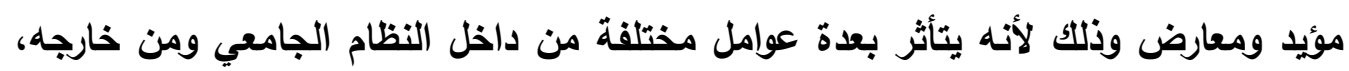

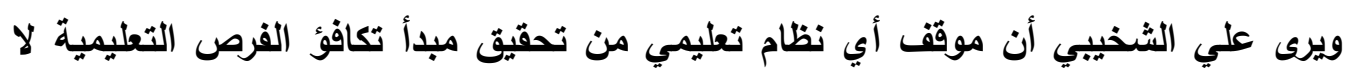

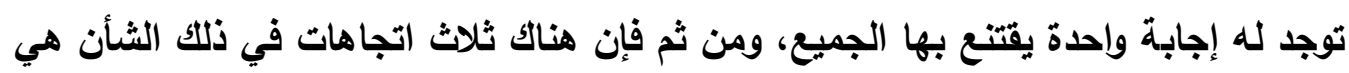

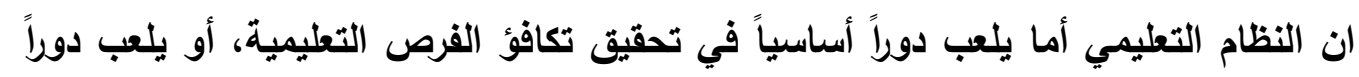
ثانوياً في تحقيق تكافؤ الفرص التعليمية، أو يلعب دوراً ثانوياً في عدم تحقيق تكافؤ الفرص

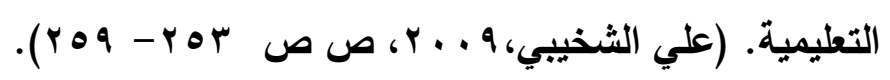

لعل من أبرز الانتهاكات لمبدأ تكافؤ الفرص التعليمية، اختلاف وتنوع أنماط التعليم ما قبل هل الجامعي - عربي/ لغات، حكومي/ خاص، مدارس حكومية- فصولها مكدة بالطلاب، ولا تتمتع بإمكانيات تعليمية حقيقية يلتحق بها الأغلبية ومدارس أخرى يسدد تلاميذها آلاف الجنيهات، مقابل الحصول على خدمة تعليمية متميزة تؤهلهم بكل أفضل لامتحان التهات الثانوية

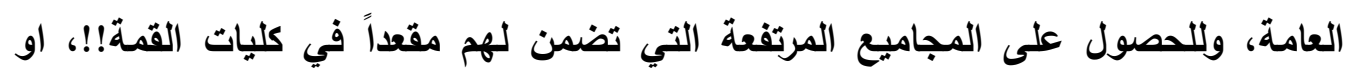
الكليات التي ما زال عليها قدر من الطلب الاجتماعي بجانب انتهاكات أخرى أنتجها تدهور

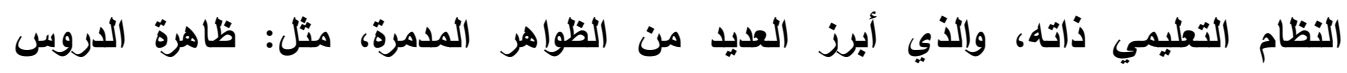
الخصوصية، وهذه الظاهرة لها تأثيراتها المدمرة على أساليب التعلم ذاتها، وتصفية الدور 
التعليمي والتربوي للمدرسة، فضلاً عن أنها تصفي واقع المجانية، الذي طالما اعتمد عليه مبدأ المساواة في تكافؤ الفرص، عند الالتحاق بالتعليم الجامعى.

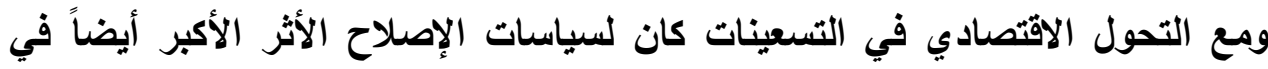
تفجير الصراع الاجتماعي في مجال التعليم، ونسف مبدأ تكافؤ الفرص التعليمية، بتعدد مظاهر التمايز في الواقع التعليمي المصري، والتي عمقت من مظاهر اللامساواة التعليمية

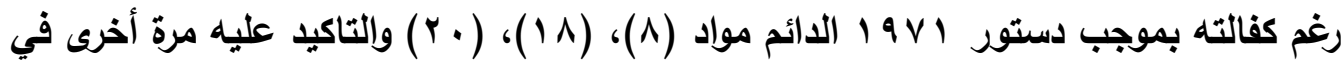
دستور V . . . المحدث نفس المواد، ومن بين هذه العوامل: 1. نثأة الجامعات الخاصة والتي طالما عارضها الكثيرون لكونها تخل بمبدأ تكافؤ الفرص لته وتوفر للقادرين نوعية متميزة من التعليم لا يحصل عليها غير القادرين، إلا أنها أنشئت مع نمو جماعات مصالح ترغب في أن تتاح لها فرصة للاستثمار في مجال التعليم

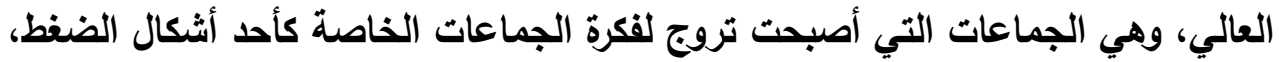
والذي توافق مع رغبة شرائح اجتماعية أخرى ترغب في توفير التعليم العالي لأبنائها، بصرف النظر عن قدراتهم الذهنية، طالما يملكون تكلفته، ويتوقع الخبراء أن تزايد معدلات الخصخصة في التعليم العالي سوف يتنامى، وسوف ينتج فرصاً اوسع لشرائح عليا في المجتمع للالتحاق بالتعليم العالي، وسوف يؤثر ذلك تأثيراً عكسياً على فرص التعليم للفئات الفقيرة. وتشهد بهذا رسوم الدراسة في الجامعات الخاصة في مصر إذ تتراوح بين ه - ه P ألف جنيه مصري سنوياً فيما يصل متوسط المصروفات الدراسية بالجامعة الأمريكية إلى ؛ 1 ألف دولار في السنة (ع ألف جنيه مصري وهناك إهدار لمبدأ تكافؤ الفرص التعليمية بالتعليم الجامعي المصري حيث إن معايير القبول في الجامعات

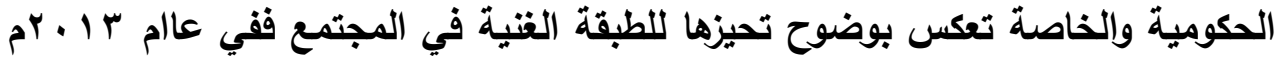
كان الحد الأدنى للقبول بكليات الهندسة في الجامعات الخاصة ه \% وفي المقابل ץ.؟ \% في الجامعة الحكومية وكانت كليات الإعلام والفنون التطبيقية والسياسة والاقتصاد والتجارة تقبل الطالب الحاصل على • ٪\%، في حين في الجامعات الحكومية

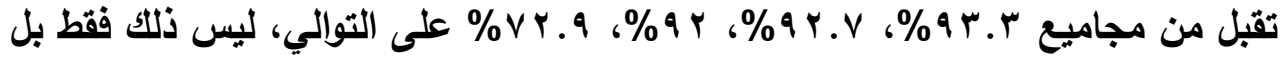
التعليم الحكومي يلزم الطلاب بشروط التوزيع الجغرافي وهذا غير موجود بالقطاع

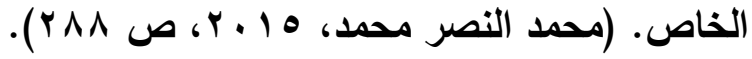


ومازالت تلك الفروق موجودة حتى عام 17 • بم وكان بتنسيق هذا العام تقبل كليات

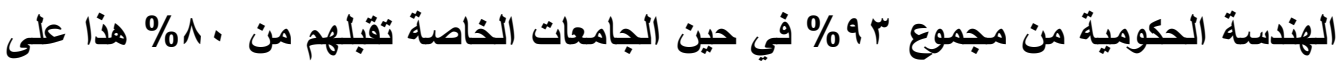
سبيل المثال، وكليات الطلب بالجامعات الحكومية تقبل من ^و\% هي حين الجامعات الخاصة تقبل من مجموع ، 9\%، وذلك يعني عدم تكافؤ الفرص التعليمية في القبول والالتحاق بالجامعات حيث تكون الفرص التعليمية من نصيب الطلاب الأغنياء وليس من نصيب الطلاب الموهويين وذوي القدرات، بالإضافة إلى وجود بعض الكليات مثل كلية الإعلام بجامعة القاهرة وتقتصر القبول على منطقة القاهرة الكبرى مما يشكل ظلم لطلاب الأقاليم الأخرى. r. نشأة الجامعات الأجنبية وما يترتب عليها من التمييز في مستويات التاهيل التي يحصل عليها الخريجون وما تتيحه لهم من فرص، فهناك تفاوت واضتح في مستوى التاهيل بين خريجي الجامعة الأمريكية على سبيل المثال، ومستوى خريج الجامعة المصرية، وهو التمييز الأي سوف يمتد إلى الجامعات الأجنبية الأخرى، وما يستبعه هذا من تحسين شروط دخول خريجي هذه الجامعات إلى سوق العمل، ويالتالي الفرص المتاحة أمامهم، مقارنة بأقرانههم من خريجي اجامعات المصرية في نفس التخصص( حسن محمد حسان

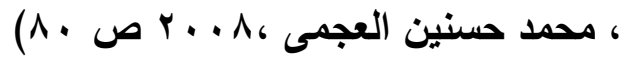
r. تعميم أقسام اللغات بالمصروفات في كل كليات الجامعات المصرية الحكومية، كماهو الحال في كليات الاقتصاد والعلوم السياسية والتجارة والحقوق، وما له من تأثيرات سلبية حتى على الطالب المتفوق، إذ سوف يجد نفسه في النهاية يتعلم تعليماً من الدرجة الثانية في نفس الكلية مع قرينه الأي قد يكون حصل على مجموع أقل منه لكنه تخرج في مدرسة لغات وقادر على دفع المصروفات. فضلاً عن التمييز في مستويات التأهيل التي يحصل عليها الخريجون في الكلية الواحدة، نتيجة لتنوع لغة التريس بها بين أقسام مجانية تدرس باللغة العربية، وأقسام غير مجانية للاراسات باللغات الأجنبية . ع. تنامي الدعوة إلى تخفيض عدد الملتحقين بالجامعات تلك الدعوة التي تتنافى مع اعتبارات العدالة كما تتنافى مع اعتبارات الكفاءة، والتي جاءت تماهياً مع رأي البنك الاولي بالتركيز على التعليم الأساسي كونه الأساس في عملية التنمية، والتقليل من الأهمية النسبية لاور التعليم العالي في الدول النامية ومن بينها مصر • إلى جاتب بروز العديد من المؤسسات التي أصبحت تؤدي دورها كجماعات ضغط، من اجل الحفاظ على 
المصالح المهنية لأعضائها، وكان لبعض هذه المؤسسات، كنقابة الأطباء ونقابة المهندسين بعض المطالب المتعلقة بالتعليم العالي، ومن ذلك المطالبة بتقليص أعداد المقبولين بكليات الطب وإلهندة، وكذلك كاتت نوادي هيئة التدريس تمارس الضغط من أجل تحسين جودة وكفاءة التعليم الجامعي، وهي المطالب التي كاتت تصب في التهاية في تقليص الأعداد المقبولة بالجامعات، على الرغم من أن نسبة الملتحقين بها لم تصل إلى المستوى العالمي • ؛ \% من إجمالي الثريحة العمرية (ب ب-1 I) سنة حيث وصل عدد المقيدين في التعليم العالي من هذه الثريحة العمرية في مطلع الثمانينات 1\% ووصلت هذه النسبية أواسط التسعينات إلى حوالي 9 1\% في حين وصلت في العام

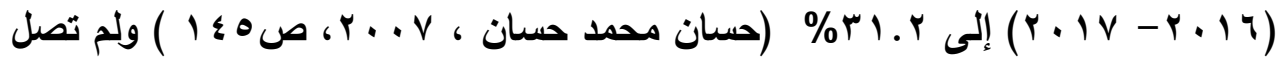
إلى المستوى العالمي حتى الآن . هـ فالمؤشرات الكمية للاستيعاب في كافة مراحل التعليم العام: الابتدائي فالإعدادي فالثانوي العام والفني وكذا التعليم العالي والجامعي، تؤكد على فشل السياسة التعليمية الحالية والتي تنتهجها وزارتي التربية والتعليم، والتعليم العالي والبحث العلمي، دون تحقيق التكافؤ في فرص التعليم، "فالسياسة التعليمية الحالية في مصر لا تحقق الأبعاد الإنسانية والاجتماعية والسياسية والتنموية لمبدأ تكافؤ الفرص التعليمية بين أفراد المجتمع المصري". وفي الصحف الرسمية (هانى هلال، ^ . . ؟ )، إثارة إلى بوادر الأخذ بهذه الاعوات فتم تخفيض ميزانية التعليم العالي في الفترة الأخيرة بمقدار . . 7 مليون جنيه ذهبت لتطوير التعليم الأساسي، كما تم تخفيض أعداد المقبولين في كليتي الطب والصيدلة في إطار منظومة تحقيق الجودة كما جاء على لسان وزير التعليم العالي. 1. اتساع ظاهرة الدروس الخصوصية تحت ضغط الحاجة الملحة إلى التفوق - كما نعثقدوقصور النظام التعليمي عن القيام بواجباته ليعمل بها مدرسون وأساتذة جامعيون، رغم

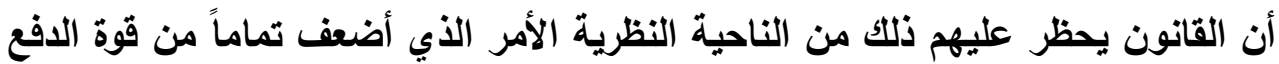
الرامية إلى تحقيق المساواة منذ الحقبة الناصرية وحتى آلان. وما تعنيه هذه الظاهرة من أن النظام التعليمي في مصر يتم خصخصته بشكل غير مباشر ليتعاظم الإنفاق العائلي/ الأسري على التعليم رغم ضمان مجانيته بنص الاستور المادة (·r) رغم عدم قدرة الأسرة المصرية على تحمل هذه الأعباء إذ يوجد Vor.V\% من الأسر المصرية تحت خط 


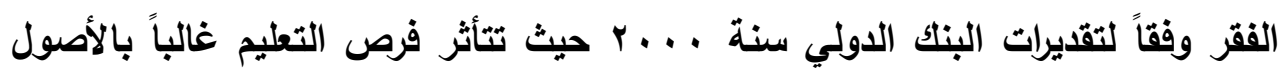

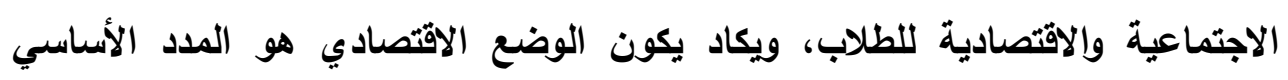

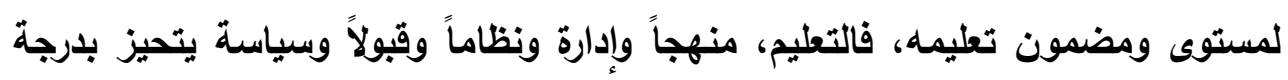

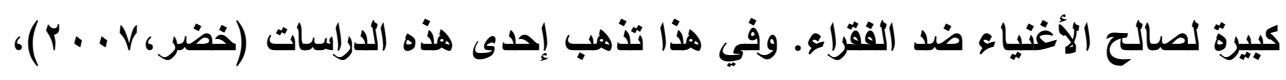

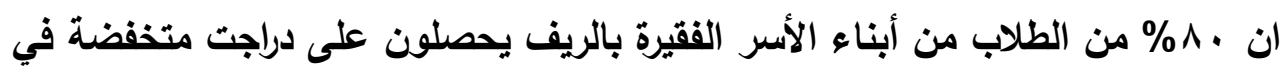

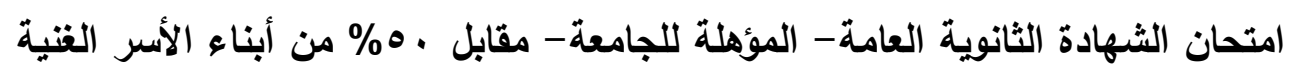

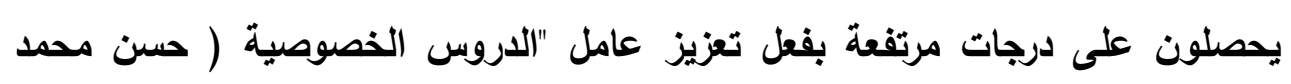

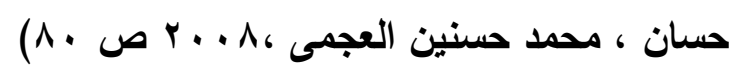

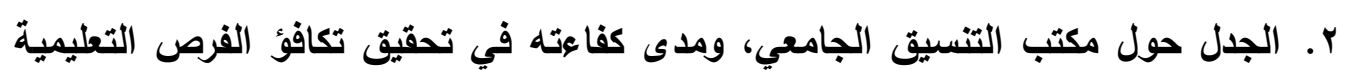

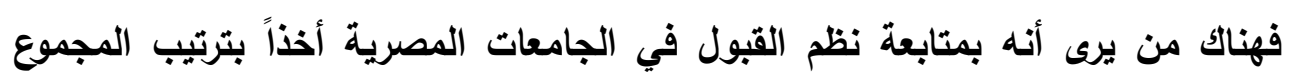

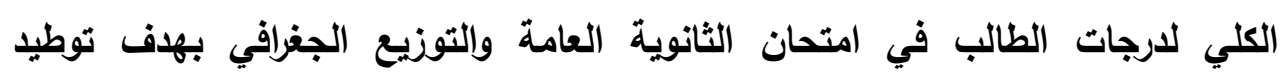

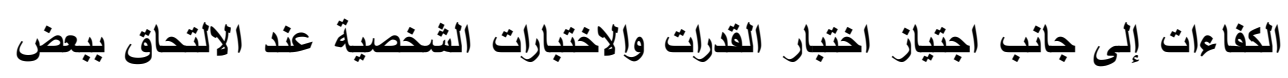

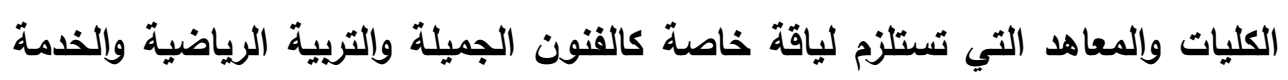

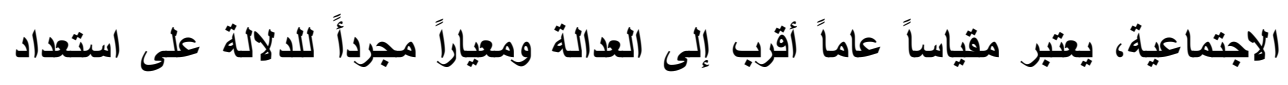

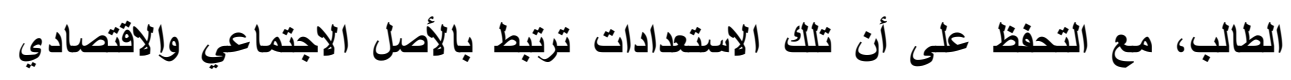

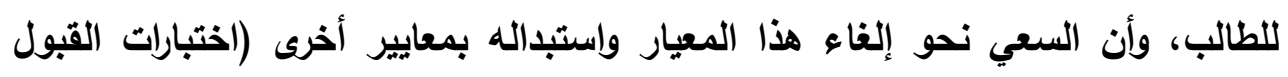

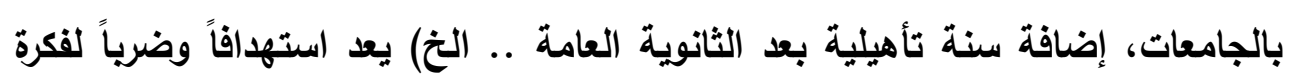

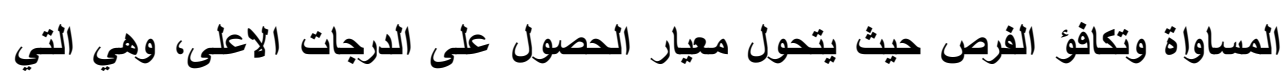

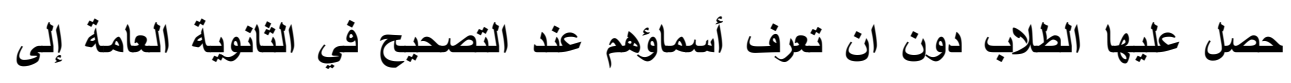

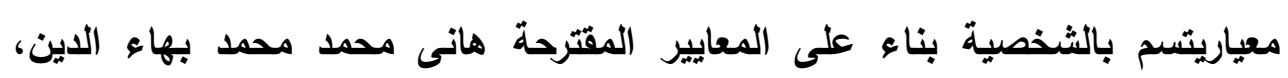

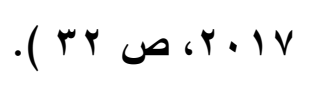

وهناك من يرى أن الاحتكام لمعايير مكتب التنسيق دون مراعاة أدنى اعتبار لرغبات

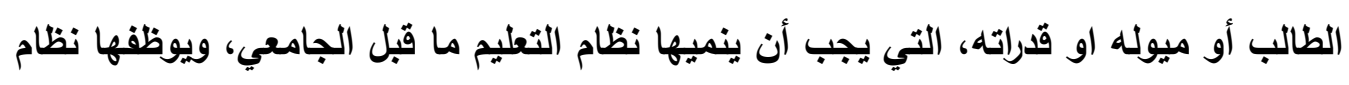

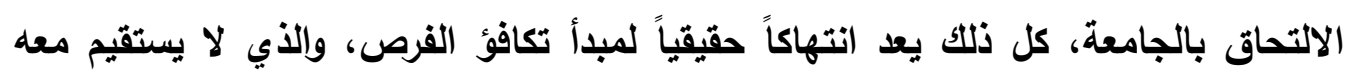

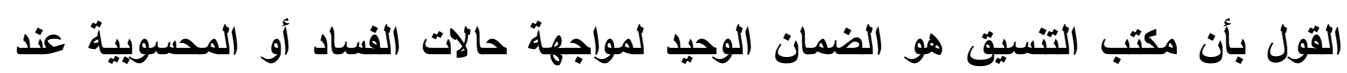

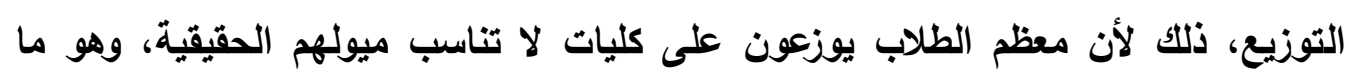




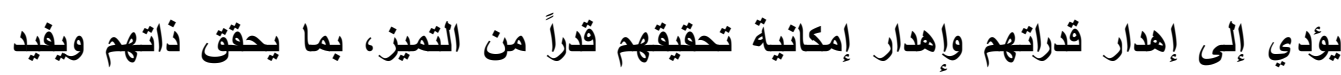

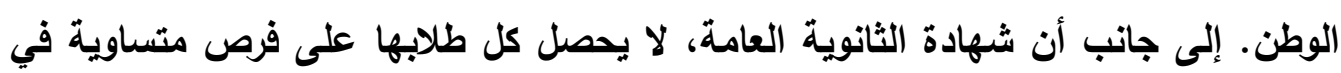

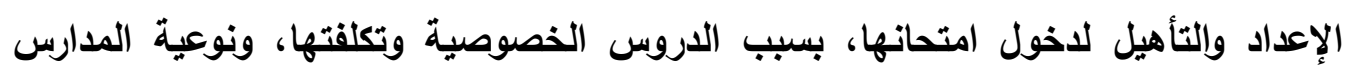

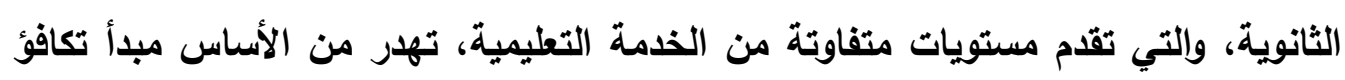
الفرص، الأمر الذي يجعل من نظام التنسيق الذي قصد به تكافؤ الفرص نهاية محبطة لآمال الكثيرين.

ورغم هذه الاختلالات بمبدأ تكافؤ الفرص التعليمية كما أقرتها الدراسات إلا أن هناك

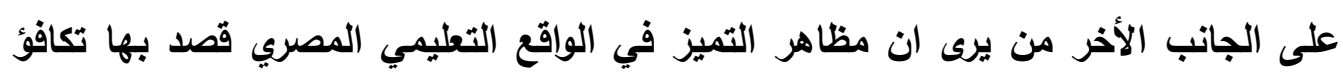

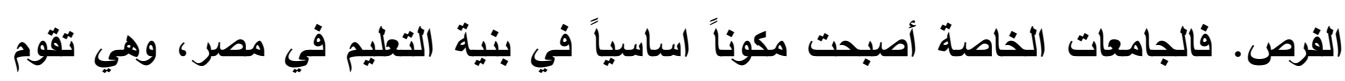

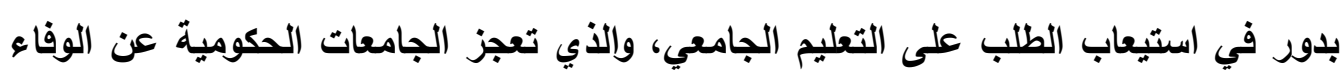

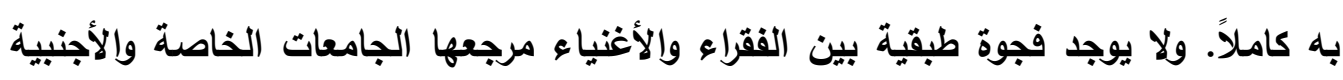

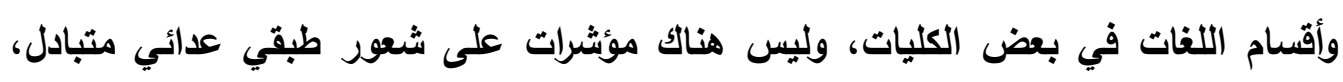

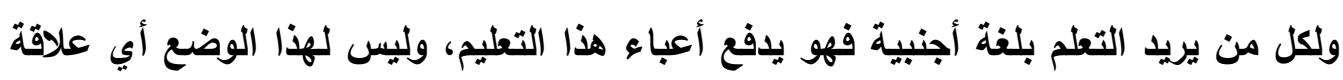
بالطبقية أو تكافؤ الفرص في التعليم الجامعي.

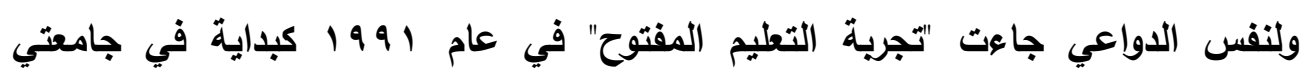

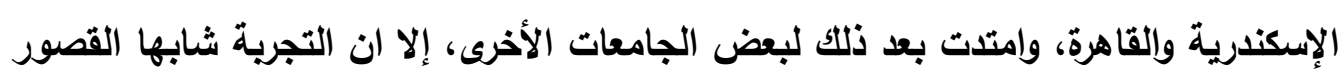

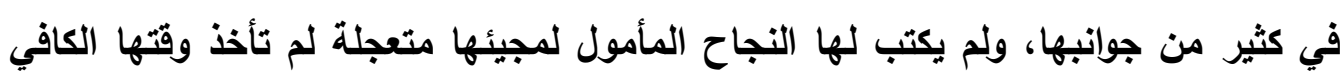

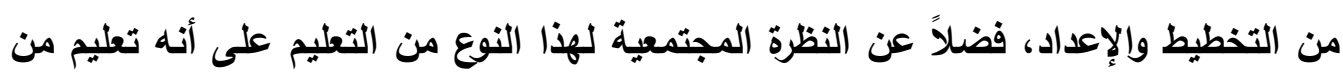

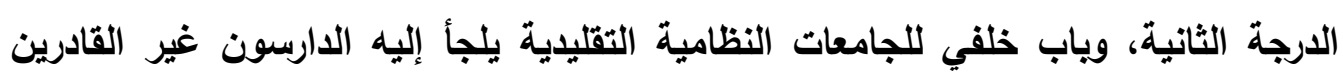
أصحاب الحظ العاثر بسبب تدني معدلاتهم التعليمية أو ظروفهم الاجتماعية أو الاقتصادية،

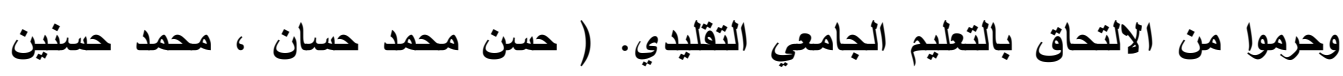

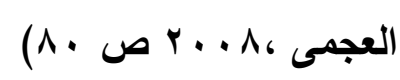

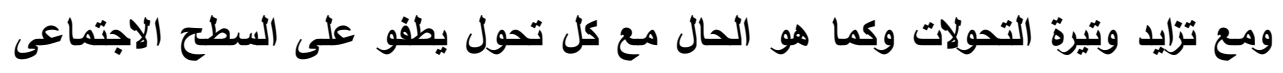

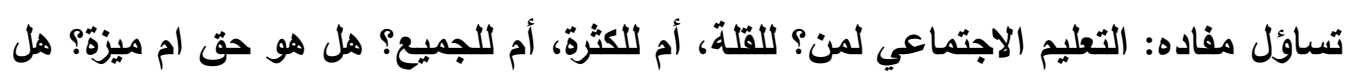

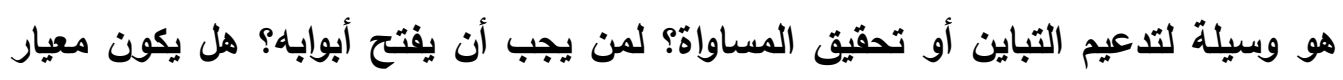
الاختيار "اصطفائياً"؟ أو على أساس "الجدارة"؟ أو المساواة في الفرص"؟ فئل المعلى الرغم م أن 
سياسة المساواة في القبول لتحقيق ديمقراطية التعليم الجامعي قد ثبتت وترسخت في كثير من الجامعات الأمريكية والأورويية، وكذلك العربية ومن بينها مصر إلا أنها لا تزال محل نقاش واختلاف والسبب في ذلك ليس فقط لأنها تؤدي إلى تغيرات جوهرية وإعادة ترتيب للاولويات لكن أيضاً لارتباطها "بصراع الأقليات" في سبيل الحصول على مزيد من الحقوق. Egalitarion Admission policies ويقصد بسياسة المساواة في القبول السياسة التي من خلالها يستطيع كل فرد في المجتمع أن يجد نوعاً من التعليم بعد المرحلة الثانوية يتناسب وقدراته ودون الحاجة إلى اجتياز اختبار قبول. فهناك العديد من علماء التربية (أشبي Ashby وجوزيف كاتز Joeph Katz وجورج بيرادي G.Berrday وكنس كلارك K.Clark) ممن أكدوا على ضرورة اتباع هذه السياسة في قبول الطلاب في عصر تفجرت فيه المعرفة وأصبح من حق كل إنسان أن يحصل على نصيبه من التعليم العالي، لما في ذلك من فائدة للفرد والمجتمع، كما أكدوا أيضا على ضرورة التظلب على المشكلات الجوهرية التي قد تعوق تطبيق هذه السياسة في بعض معاهد التعليم العالي والتي قد تتمثل في ازديياد معدل الطلب على الالتحاق مقابل محدودية الأماكن والإمكانات مما يضطر هذه المعاهد إلى رفع متطلبات القبول إلى الدد الأي قد يثير الكثير من التساؤلات حول إقرارات خاصة بتلك المتطلبات وما إذا كانت تحكمها فعلاً عوامل تريوية أم أنها تبني على عوامل متعلقة فقط بمحدودية الموارد مقابل زيادة الطلب.(Brubacher,2012,p82) وفي المقابل وجدت هذه السياسة نقاً حاداً من العديد من علماء التربية (دوركا فيرث ونسبت Nesbet وسيمور هارز S.Harris وكوفمان Kaufman) وذلك مئك على اعتبار أنها تؤدي إلى تلني في المستوى الأكاديمي وارتفاع معدلات التسرب واختفاء الدافعية للعمل ويذل الجها لاى الطلاب ويالتالي فهي لا تقدم شيئاً يذكر للعملية التعليمية

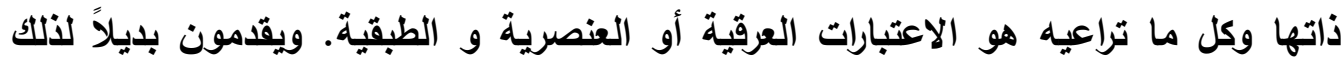
سياسة الانتقاء كسبيل لتحقيق ديمقراطية التعليم الجامعي Elitist Admission policies والتي تركز على ديمقراطية الاستحقاق أي على تحديد من تتوافر لايه القدرات التي تساعده

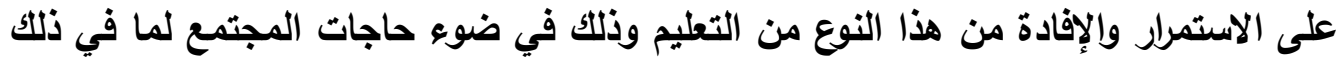
من فائدة لكل من الفرد والمجتمع، ولا يزال أصداء هذا الجدل قائماً ما بين السكون والصركة هونة وفقاً لمقتضيات الواقع الإجتماعي(Brubacher,2012,p85). 


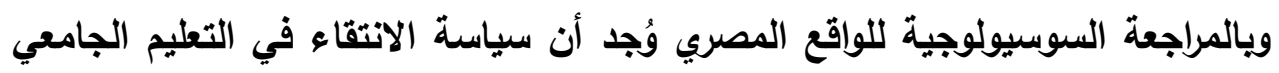

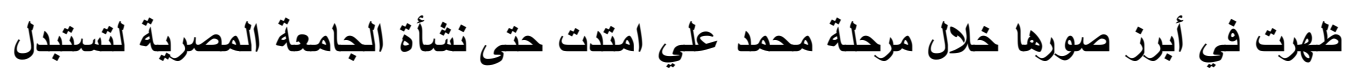

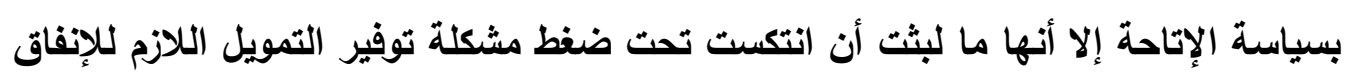

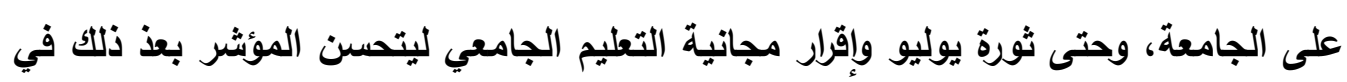

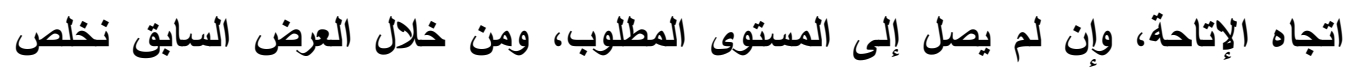

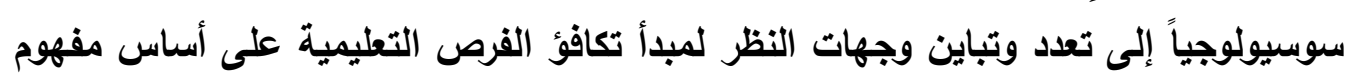

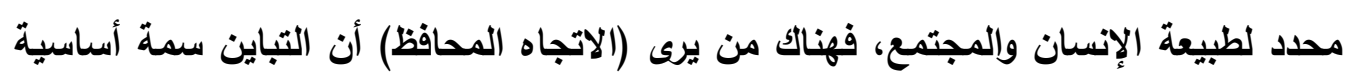

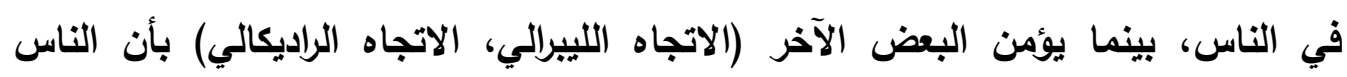

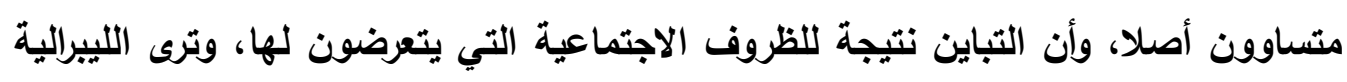

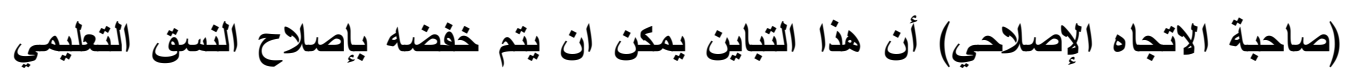

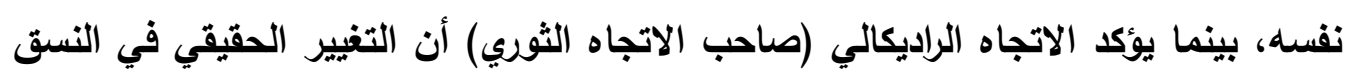

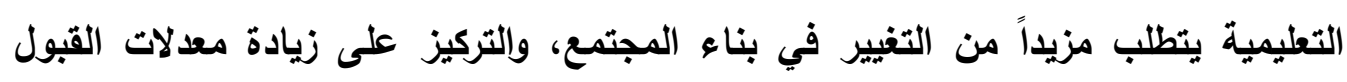

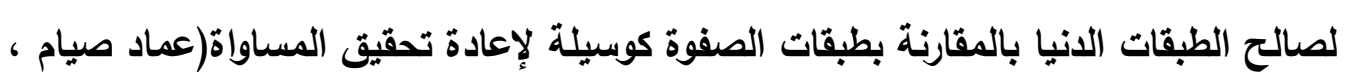

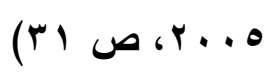
وأياً ما كان مرد "التباين" يظل هو الحالة القائمة، والقاسم المشترك فيما بين الرأيين، وعليه

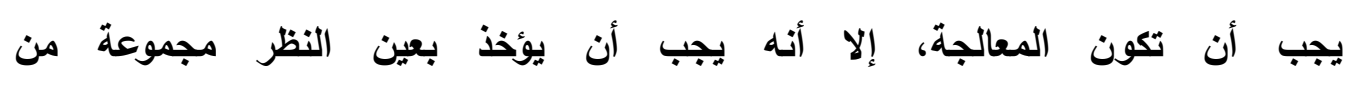
الاعتبارات:(Brubacher, 2012,p82)

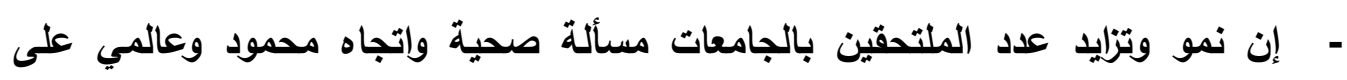

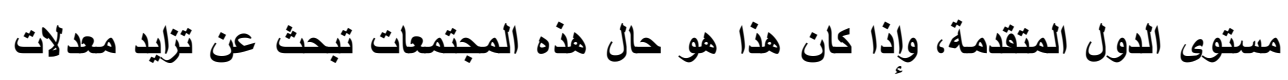

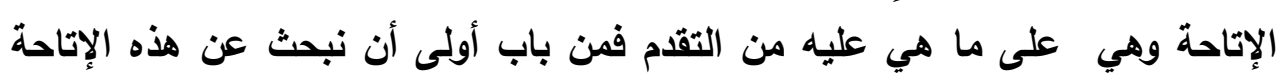

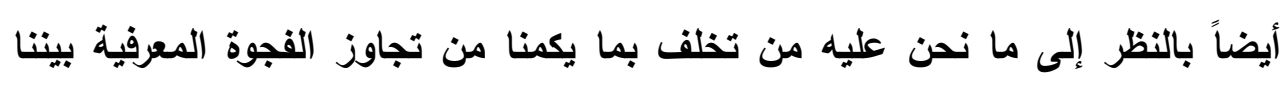

ويينهم.

- يجب أن يكون التعليم العالي متاحاً للجميع، حتى يمكن مواجهة التغيرات الاجتماعية

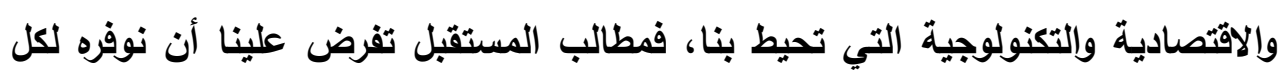

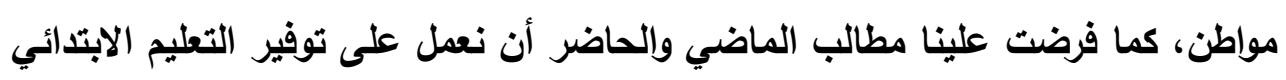
(أو الثانوي) لكل فرد ، بصرف النظر عن قدراته الفردية أو وضعه الاجتماعي. 
- - ديمقراطية التعليم العالي - تكافؤ الفرص - عملية تمتا جذورها الحقيقية الى مستويات

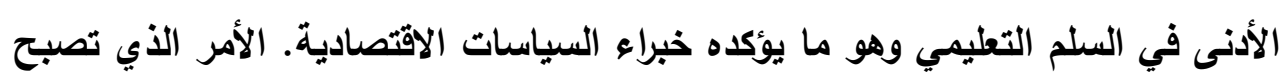

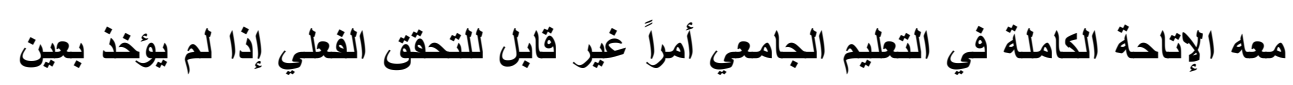
الاعتبار عمليات الانتقاء التي تتم في مرحلة ما قبل الجامعة.

أما فيما يتعلق بـالمعالجة فيمكن أن توجه الجهود في اتجاهين :

الأول: يتجه نحو توحيد معايير القبول الجامعي بين الجامعات (حكومية/خاصة/أجنبية) ومراعاة متطلبات الجودة التعليمية في كل منها، واعتماد هذه الآلية أسلوياً من أساليب تطوير التعليم الجامعي، حتى لا تتحول إلى مجتمع مستقطب يستطيع

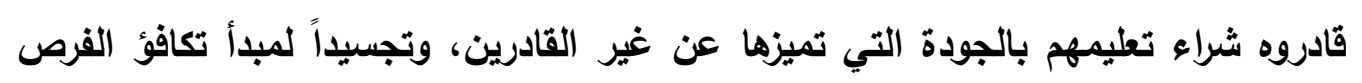

.Equal Opportunity

الثاني: يتحتم على التعليم الجامعي في ظل إخفاقه في تحقيق تكافؤ الفرص، وفي ظل الطلب الاجتماعي المتزايد التوجه إلى أنماط جديدة من التعليم، أكثر مرونة، وقدرة على فئ فئي

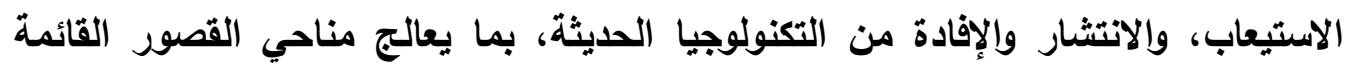

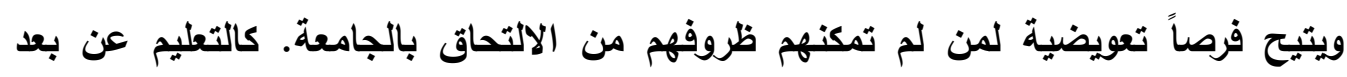

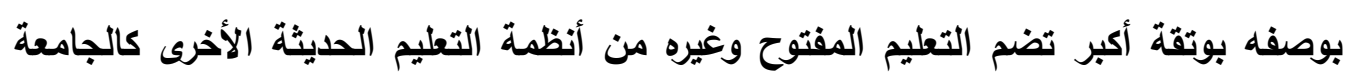
الافتراضية، والجامعة الإكترونية والتعليم المستمر والتعليم بالمراسلة .. ألخ تختفي بموجبه وفيه

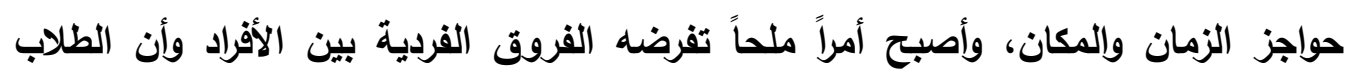

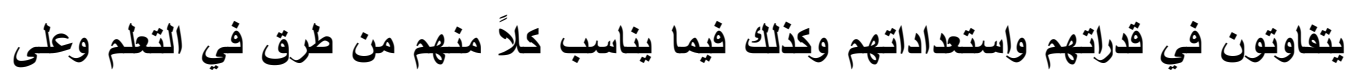

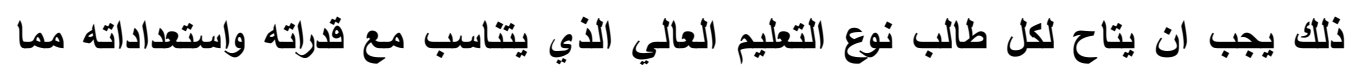
يجعله ينمو إلى أقصى درجة تسمح بها هذه القدرات وتلك الاستعدادات مع مراعاة أن طبيعة

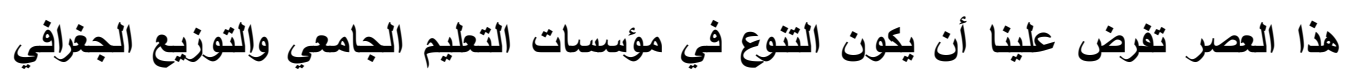
لها، والأخذ بأساليب وأنماط جديدة للتعلم "تنوعاً" في إطار الوحدة وليس تشنتاً وإختلالاً في توازن الوظائف والاختصاصات بما يحقق حاجات المجتمع ويجسد مبدأ تكافؤ الفرص التعليمية ويخفض الفاقد في مجال بناء الإنسان. 
رابعاً: علاقة مجانية التعليه بتكافؤ الفرص التعليمية بالتعليم الجامعى فى ضوء التحليات

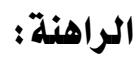

استكمالاً لمجانية التعليم وتكافؤ الفرص كان تحييد العامل المادي أحد الوسائل

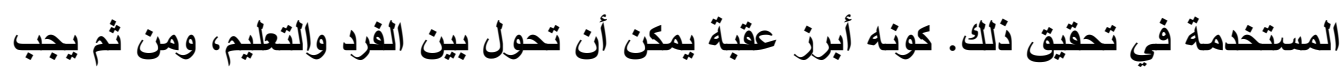

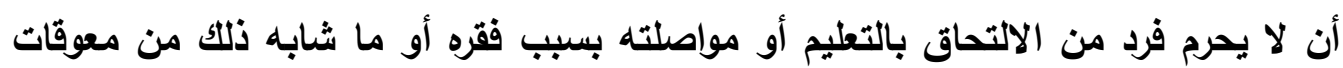

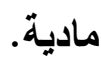
وتحتل الإجراءات الرامية إلى تنليل المعوقات المادية، مكان الصدارة في تجارب معظم

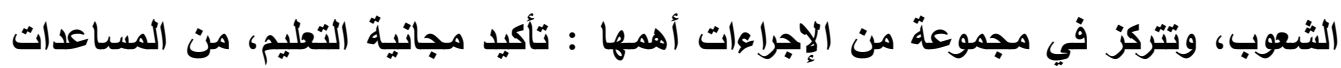
للمحتاجين، تيسير الحصول على القروض الميسرة للارسين، توفير وسائل مواصلات بأسعار معقولة، نثر الجامعات بثكل يقتضي عدم تركيزها في مناطق دون اخرى، العناية بصحة الفيرة الدارسين بتظذيتهم وعلاجه إلى غير ذلك، ورغم تعدد الإجراءات تأتي مجانية التعليم كأقدام وأثشهر الإجراءات التي يلجأ إليها لتأكيد المساواة أمام الفرص التعليمية المتاحة.

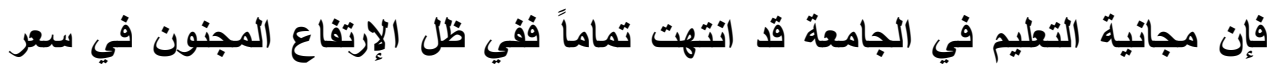

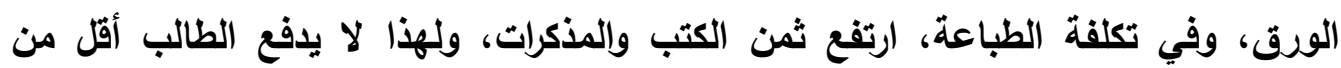

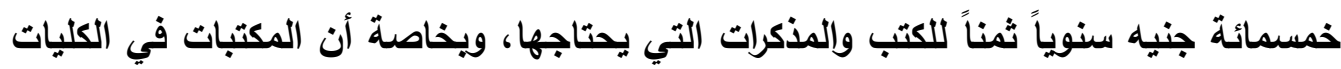

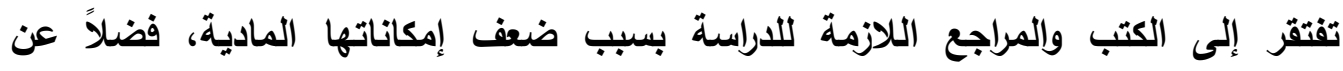
المشروعات البحثية التي تتطلب خامات ومواد تعليمية غير متوفرة بالكلية، تستفف طاقات الكاتي المتعلمين، كما أنها تستنزف إمكاناتهم المادية. ويذلك يتحول التعليم العالي تدريجياً إلى آلية لتكريس الفوارق الاجتامعية. وفي اوائل

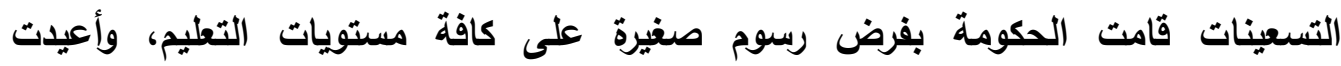

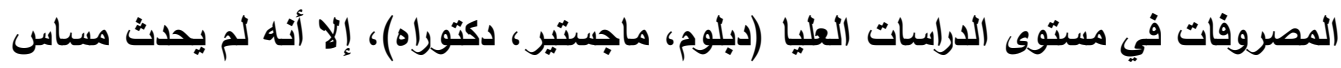

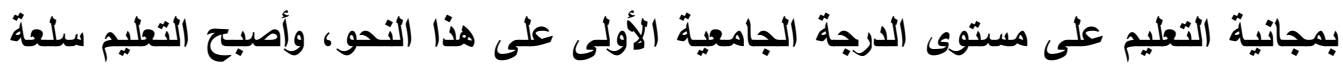
داخل سوق يحكمه قانون العرض والطلب ولا يقدر عليه إلا فئة قليلة مع تنامي التعليم الخاص والأجنبي، وتعميم أقسام اللغات بالمصروفات في كل الكليات، ولا يزال الحديث عن التان المجانية وارداً ومتجداً كلما اشتدت الأزمات والضغوط الاقتصادية ما بين مؤيد ومعارض،

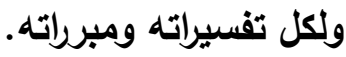


المعارضون يرون إلغاء هذه المجانية على أنها لم تكن فيما مضى سوى أداة

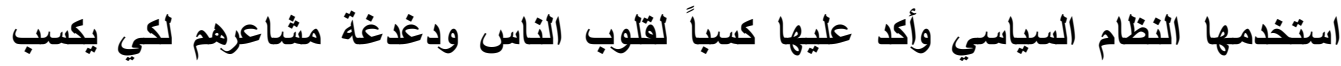
شعبيته ومن ثم شرعيته. وكان الوجه الآخر للعملة هو التزام الدولة بتثغيل الخريجين وضمان توظيفهم ولا يزال اللعب بهذه الورقة - المجانية - قائماً كوسيلة لنفس الغاية. ويقولون بانتهاء عصر الاتكال على الدولة، وأن الدولة لم تعد مؤسسة خيرية تعلم وتسكن وتوظف .. الخ. كما أن التعليم سلعة ويأن كل سلعة وكل خدمة لها تكلفتها، وأنه طبقاً لمبدأ العرض والطلب ليس من حق الإنسان أن يتعلم طالما ليس معه تكلفة ومصاريف تعليمه. لأن

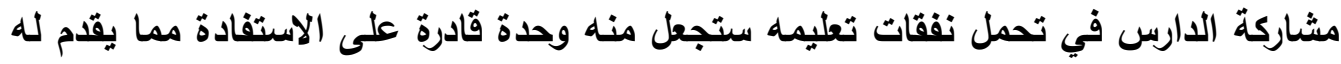
من تعليم بالكم والكيف المطلوبين. وعلى ذلك يشيعون أن التعليم الخاص أفضل من الحكومي

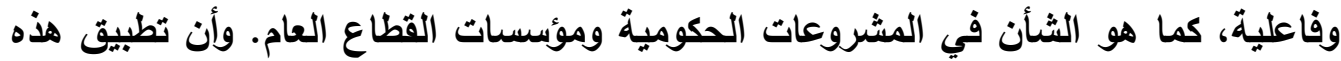

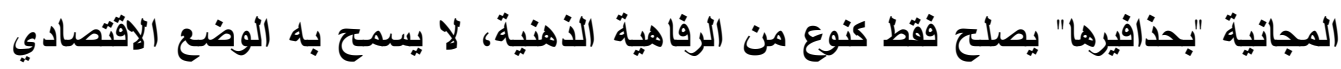

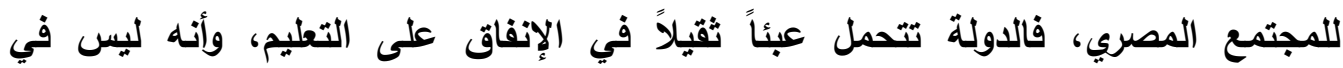
استطاعتها أن تنفق عليه معدلاً أكبر مما تنفق حالياً وهي في حاجة إلى مزيد من الآنيال التمويل. ويرون أن المجانية في حد ذاتها هي السبب في تدهور مستوى التعليم، وغلبة الانتشار العددي (الكمي) على حساب الكيف (الجودة)، وقصور البنية التعليمية (منثأت وتجهيزات)، واستخدام هذه المجانية رخصة للرسوب عملاً بثقافة "أبو بلاش كتر منهة"، فضلاً عن تزايد عدد خريجي الكليات النظرية مقارنة بنسبة الخريجيين الفنيين والعمليين، وتركيز المناهج على ملكة الحفظ دون الاهتمام بالقدرات الخلاقة والعملية لاى الدارسين مما ترتب عليه مشكلة البطالة من خريجي الجامعات. ورغم ذللك فهناك تحيز حكومي واضح للتعليم الجامعي

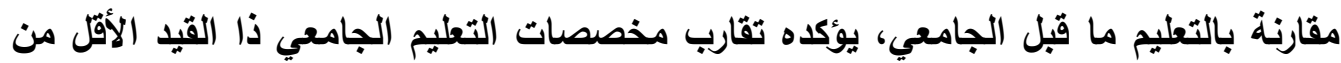

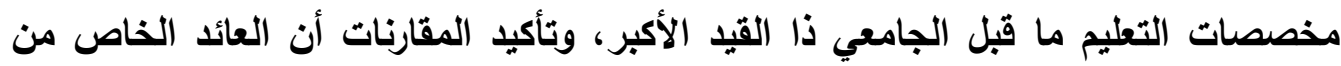

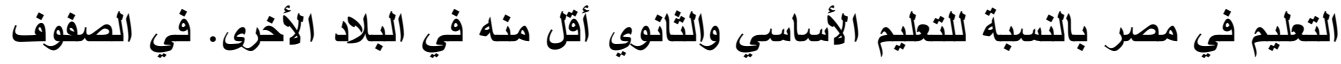
التالية على عكس ما يذهب إليه البنك الدولي الرافض لمجانية التطليم الجامعي بزعم أن العائد

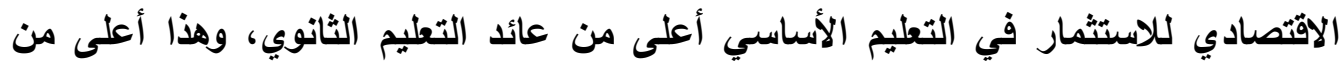

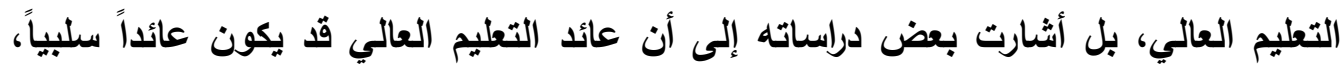
ويدعون أن مجانية التعليم العالي تستفيد منها الثرائح الاجتماعية العليا والوسطى. 
أما المؤيدون فيرون أن مجانية التعليم هي قضية اجتماعية بامتياز لا علاقة لها على الإطلاق بالنظام القائم ولا ترتبط بأيديولوجية معينة بل تمثل مكاسب جاهد الشعبه الثب عبر تاريخه

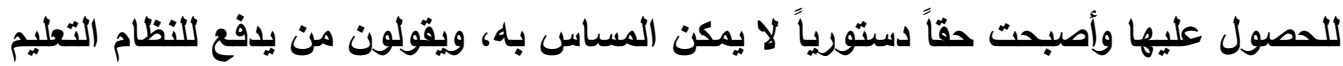
أو أي نظام آخر هو المجتمع كله في الحقيقة. فالذي يدفع للتعليم هم المصريون. المشكلة في هذه الحالة ان المصريين يحدث لهم نوع ما من الخديعة مؤداها أنه عندما تصرف الدولة فمئة معنى ذلك أن المجتمع لا يصرف. وهذا خطأ لأن الدولة تصرف من مال المجتمع عبر سداده للضرائب التي تختلف من فرد إلى آخر حسب مقدار الثرة ليستقيد الجميع. أما عن تسعير الخدمات التعليمية بقيمتها السوقية سيجعلها ليست في متتاول أولئك الذين يعيشون عند خط الفقر وتحته بمعنى أنه ليس في استطاعة جميع الدارسين تحمل جميع نفقاتهم التعليمية بالنظر إلى المستويات الاقتصادية والأحوال للمجتمع المصري، وفي لهي هذا تذهب إحدى الاراسات، إلى أن أرقام المتسربين في السنوات الاولى من التعليم العالي ترجع في غالبيتها إلى صعوية مالية تواجه هؤلاء المتسربين لا في مواجهة نفقاتهم التعليمية فحسب بل في مواجهة الظروف المعيشية لهم كذلك تلك هي حقيقة الأمر في الدول النامية

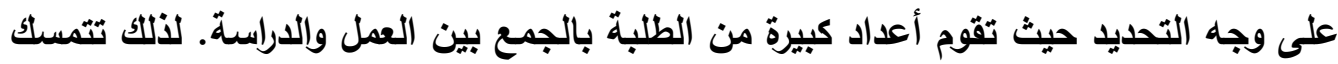
بعض المجتمعات غنيها وفقيرها بمجانية التعليم باعتبارها الاستثمار الكفيل والخروج من حالة الفقر والافتقار التي تعيشها الدولة الفقيرة، والدافعة إلى المزيد من التقدم في حالة الدول المتقدمة، فهناك دول رأسمالية مثل ألمانيا وفرنسا ويعض الدول الاسكندينافية مازالت تتمسك بمجانية التعليم في جميع مراحله بما فيها التعليم العالي وما بعده حتى مستوى الطلاب الدوليين. وطبقاً للمبدأ الأخلاقي لا يجوز حرمان الإنسان من حقه في التعليم طالما يتوافق

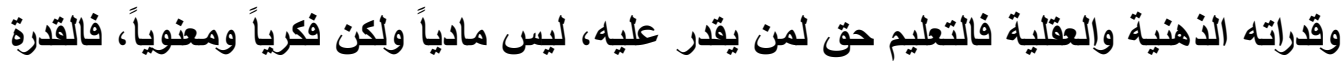
هنا تفوق البعد المادي. اما الحديث عن التعليم الخاص ودعاوي إلغاء المجانية فتتثابه مع حد كبير مع الدعاوي التي كانت تطلق على القطاع العام تمهيذاً لبيعه، وفرض نظام الخصخصة والاتجاه نحو السوق ما يجعل هذه المشابههة لا تستقيم مع الحالة الجامعية بين

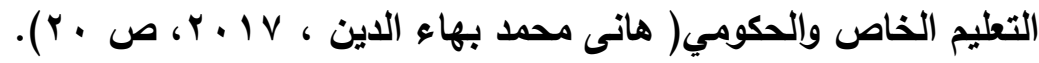
وأما ما تتحمله الدولة من إنفاق على التعليم فيعاني القصور أو ما يعرف "بالقجوة التمويلية" خصوصاً إذا ما جرت المقارنة بين أقطار العالم ذات التعليم المتطور، هيث يُمائ يتراوح 


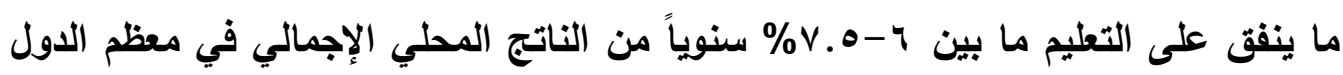

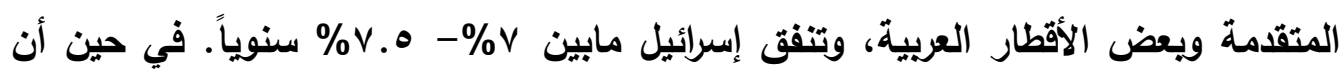

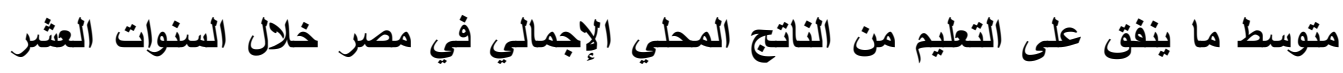

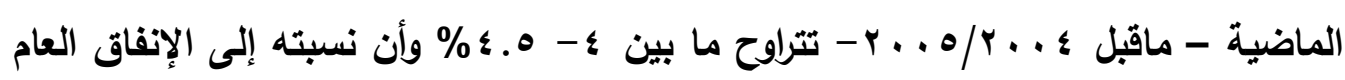

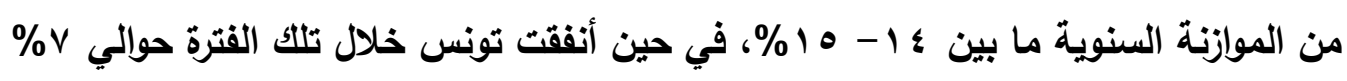

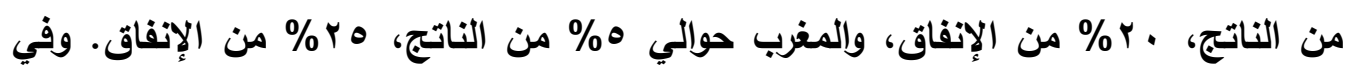

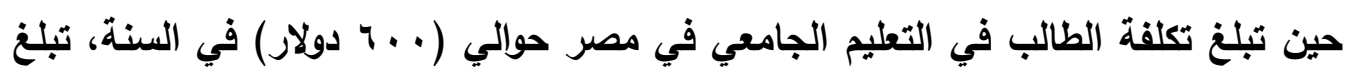

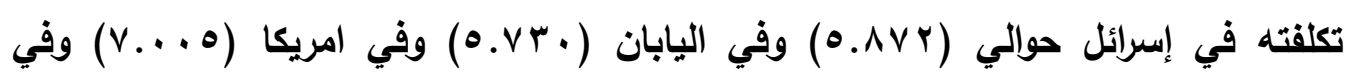

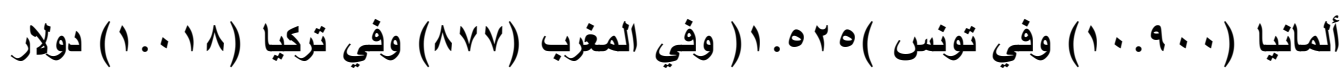

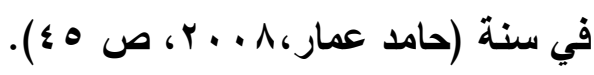
ومرد هذا التردي التمويلي يرجع في الأساس إلى قصر جهود التمان التمية وفقاً لما تقرره

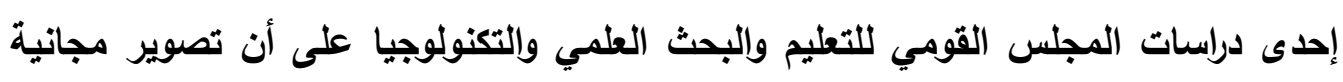

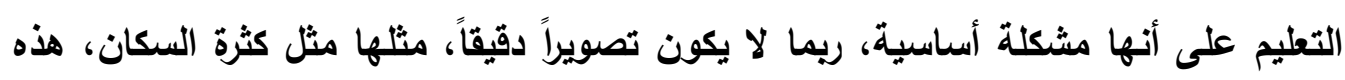

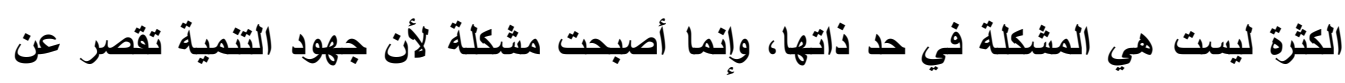

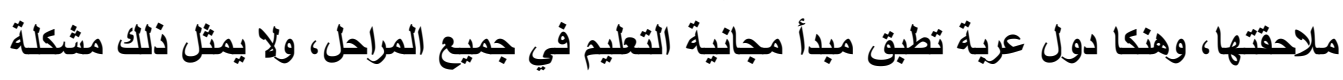

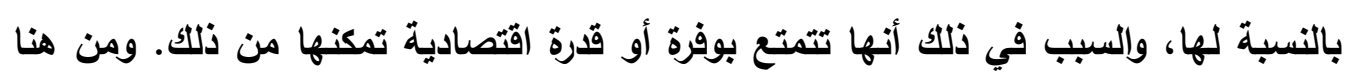

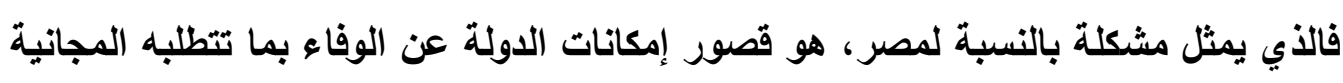

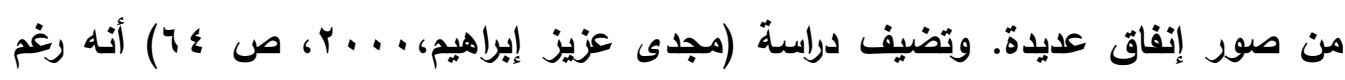

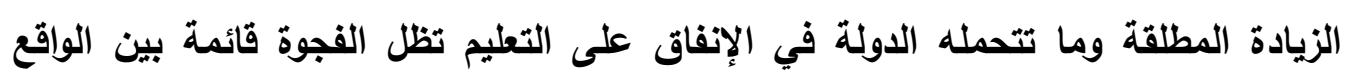

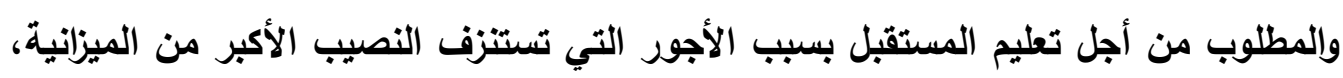

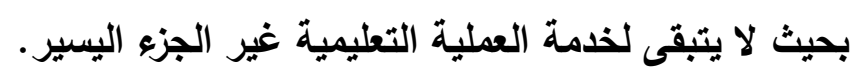
وتأسييساً على هذا يمكن تفسير تدهور مستوى التعليم، وقصور البنية الجامعية،

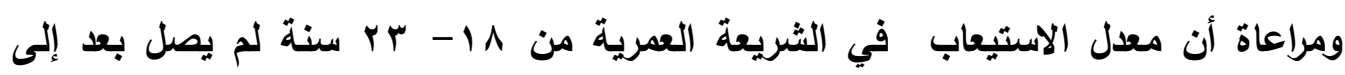

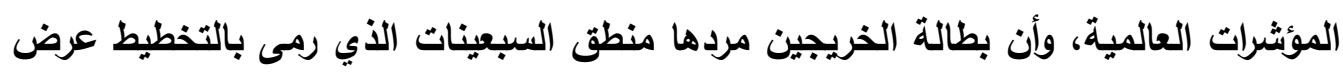

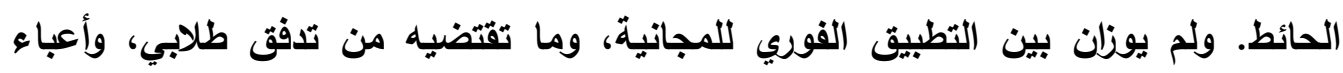

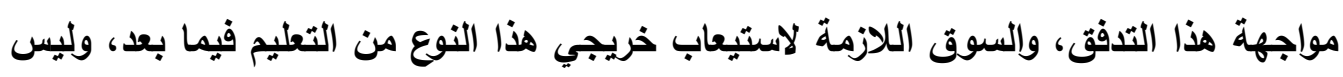


ثمة تحيز في الإنفاق على التعليم الجامعي على حساب التعليم الخاص بل هو واقع تفرضه

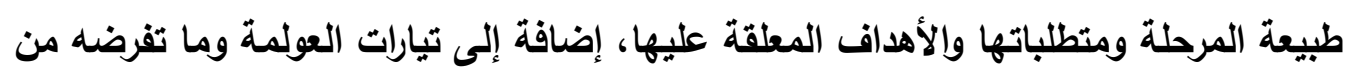

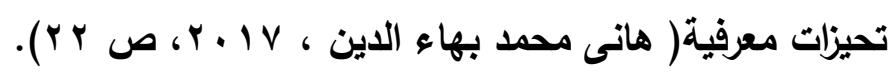

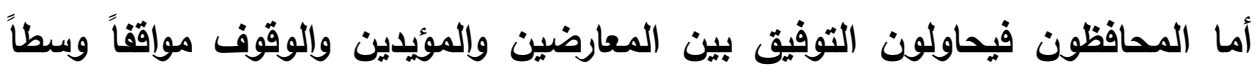
اعتقاداً منهم أن هذه المجانية يجب ان تتحرك في سياق ما يعرف بالتوازن الاجتماعي بين

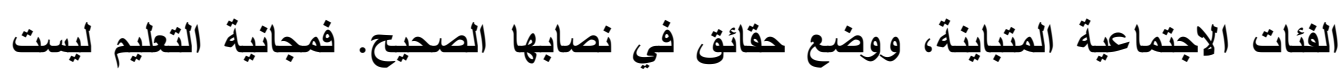

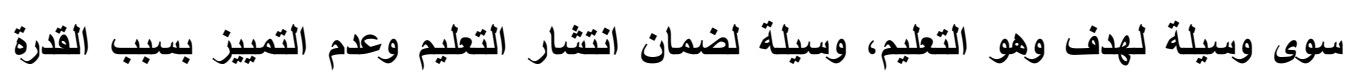

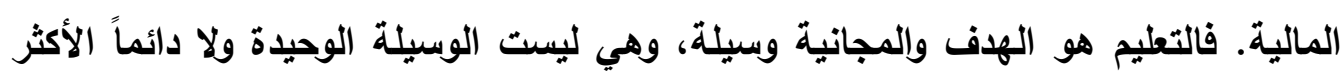

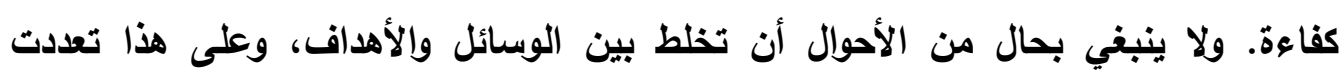

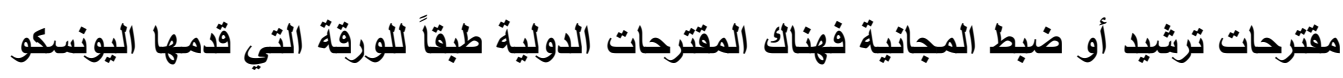

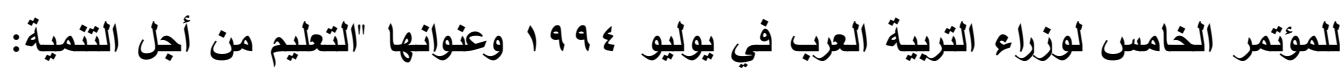

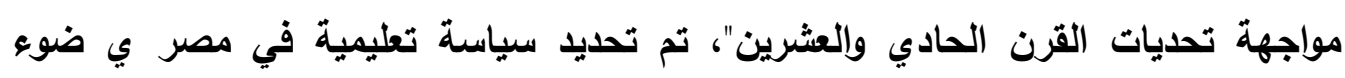

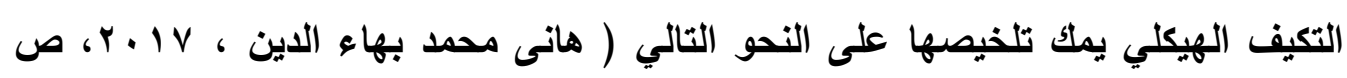
$\cdot(r \mathrm{~V}$ - مجانية كاملة في مرحلة التعليم الأساسي. - المجانية في المراحل التالية للطالب الملتزم بوظيفته الاجتماعية، بمعنى قصر المجانية على الطالب المتقوق - - يستبعد من المجانية القادرون الذين ارتضوا طواعية الإنفاق في التعليم الخاص بمرحلة

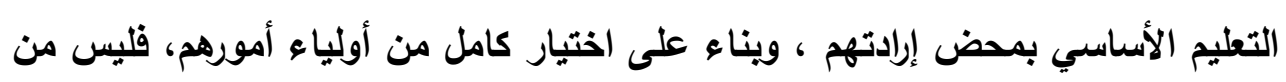

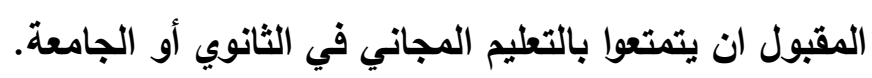

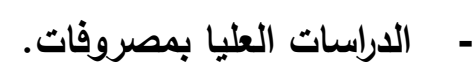
- المتفوقون يتمتعون بالمجانية في كل المراحل التعليمية، ويمنحون المكافأت، وحتى ولو بدأ تعليمهم بالتعليم الخاص، ويتمتعون بالمجانية أيضاً في الدراسات العليا.

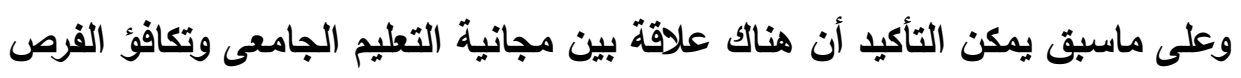

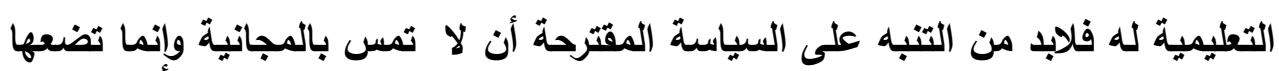

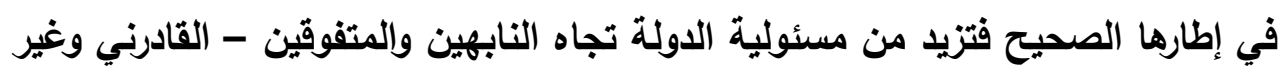


القادرين مالياً - بشكل أكثر فاعلية مما يستحقها، ودعوة القادرين في تموييل التعليم

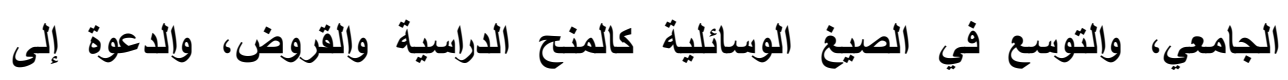
الاستقلال المالي وحرية الإدارة، وأخيراً تبقى الرؤى الثثلاث مطروحة - المئه المؤيدين

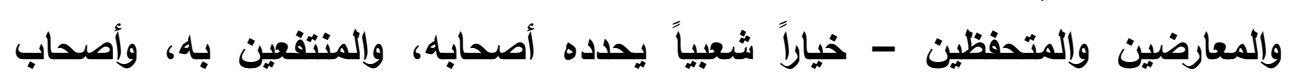
المصلحة فيه.

وأن يحصل جميع طلاب التعليم الجامعي على فرص متكافئة من الخدمات والمكونات التعليمية على مستوى جميع الجامعات المصرية وعلى مستوى جميع الكليات داخل نفس هل الجامعة وألا تستأثر جامعة دون باقي الجامعات بالجمهورية بالخدمات والاهتمام، وأيضاً ألا

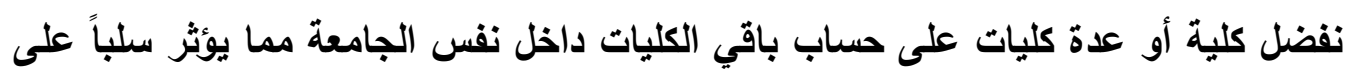

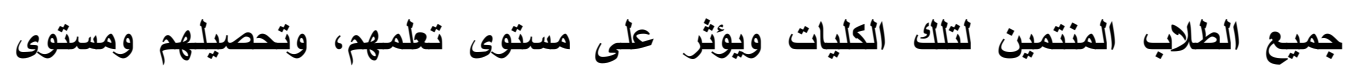
المهارات التي سوف يكتسبونها، وتتمثل تلك الخدمات في المباني والمعامل والأجهزة والمعدات والمكتبات والرحلات العلمية والتعليم الإلكتروني والمشروعات وغيرها مما يقدم خدمة للطلاب داخل الجامعة يؤثز بالتأكيا على مستواهم ومهاراتهم المكتسبة من التحاقهم بالجامعة، ولابد أن تكون هناك تكافؤ في مخرجات التعليم الجامعي من جميع الجامعات وجميع الكليات

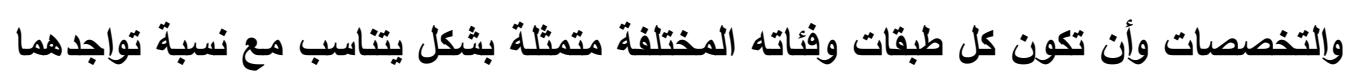
بالمجتمع ويذلك يكون قد تحقق هذا المستوى بشكل مرضي. وأن يستطيع كل فرد في المجتمع من الحصول على فرصة متكافئة مع الآخرين في في فئي

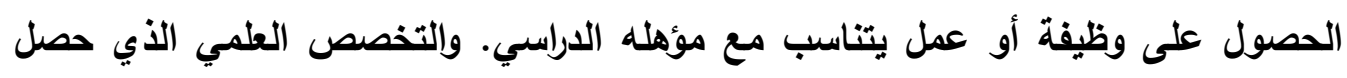

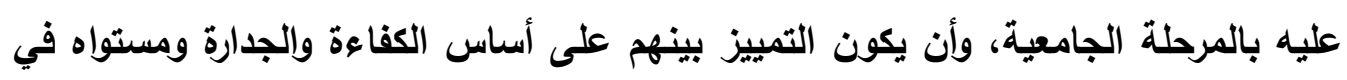
إنجاز عمله ويعتبر هذا المستوى محصلة جميع المستويات السابقة وله أهمية خاصة لأنه يمثل همزة الوصل بين النظام التعليمي وسوق العمل.

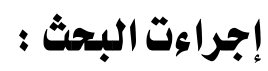
• أهـدافالدراسـة الميدانيـة: الوقوف على واقـع مجانيـة التعليم الجـامعى وعلاقتهـا بتكافؤ الفرص التعليمية فى ضوء التحديات الراهنة .

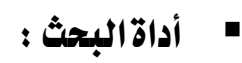


استخدم البحث الحالى استبيان خاصة بالطلاب * واستبيان خاص بأعضاء هيئة التدريس

والطلاب وقد تم بناء هذين الاستبانتين من خلال * :

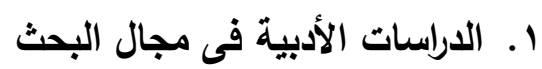

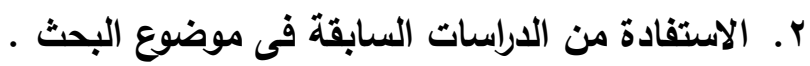

r. إجراء بعض المقابلات الثخصية مع بعض الطلاب وأعضاء هيئة التدريس .

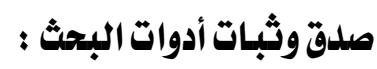

يقصد بالصدق أن تقيس الأداة ما أعدت لقياسة بالفعل ، وتوجد العديد من الطرق

التى تستخدم فى قياس صدق الاستبيانات ، وقد اتمدت الباحثة على طريقة صدق المحكمين

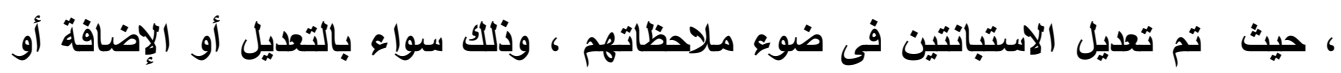

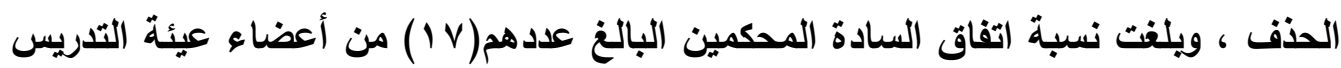

$$
\text { على عبارات الاستبانتين (^^ـ، • •). }
$$

كما يقصد بالثبات أن تكون الأداة على درجة عالية من الدقة والاتقان فيما تزودنا به

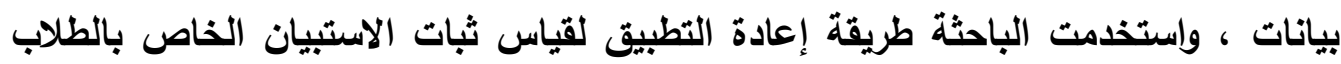

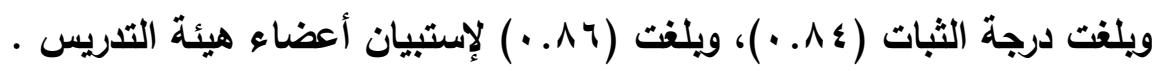

\section{عينة الدراسة :}

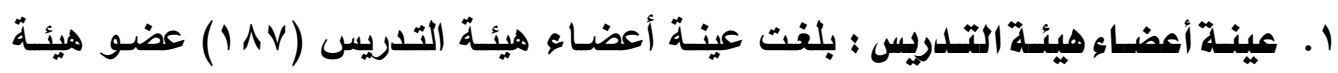
تدريس ، وقد تم اختيار العينة بطريقة قصدية عشوائية بجامعة ( الإسكندرية - عين

$$
\text { شمس - سوهاج) }
$$

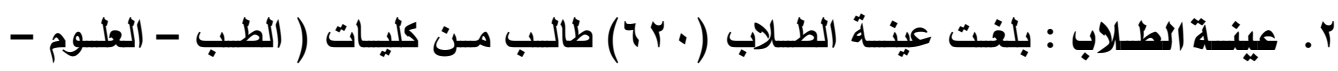

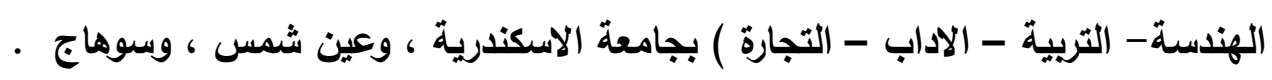

\section{المعالجة الإحصائية : المائة}

استخدمت الباحثة الأساليب التى تناسب بيانات الدراسة وتساعد على تحقيق أهدافها فقد

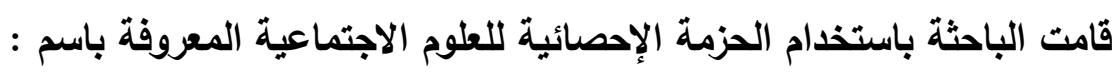



Statistical Package for the Social Sciences :Spss اللازمة للاراسة ، والمتمثثة فى: 1. حساب المتوسط الحسابى لكل فقرة من فقرات الاستبيان . r. r مساب الانحراف المعيارى لكل فقرة من فقرات الاستبيان.

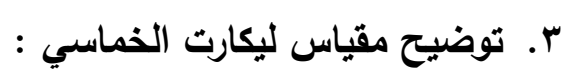

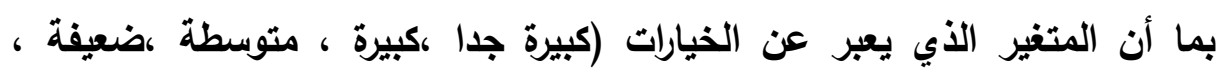

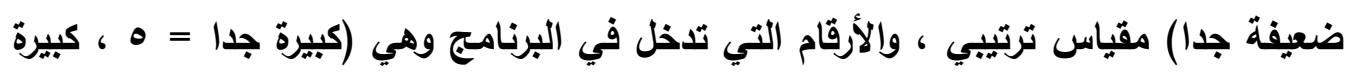

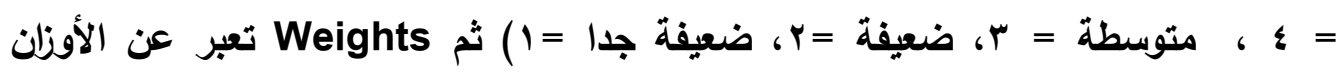
نحسب بعد ذلك المتوسط الحسابي (المتوسط المرجح) ويتم ذلك بحساب طول الفترة أولاً ،

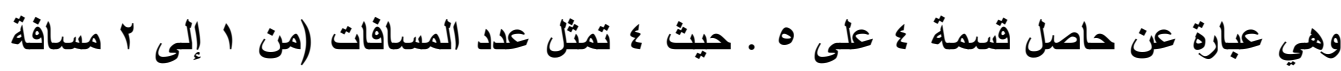

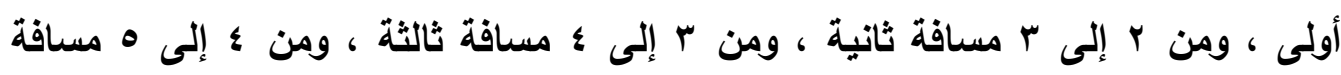

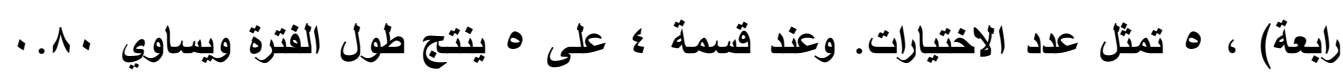

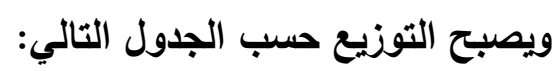
جلول(1) المتوسط المرجح

\begin{tabular}{|c|c|c|}
\hline ضعيفة جدا & إلى & من \\
\hline ضعيفة & إلى & من •^ג.1 \\
\hline متوسطة & إلى q r.r & 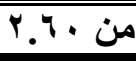 \\
\hline كبيرة & إلى 19. 19 & من ·ــ"ب \\
\hline كبيزة جدا & إلى & من ·ץ.؟؛ \\
\hline
\end{tabular}

نتائج البحث ومناقشثتها :

بعد إجراء المعالجة الإحصائية لاستجابات أفراد العينة التي وقع عليها الاختيار في بعض

تم التوصل للنتائج التالية: أولا : النتائج الخاصة بـأعضاء هيئة التدريس المحور الأول : أوجه القصوربمجانية التعليم الجامعى وعلاقتها بتكافؤ الفرص .

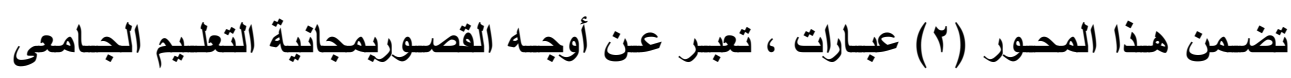

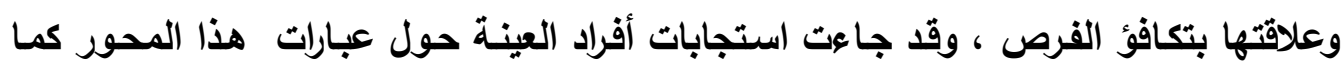


مجانية التعليم الجامعى وعلاقتها بتكافؤ الفرص التعليمية فى ضوء التحديات الراهنة وأزمة التحول.

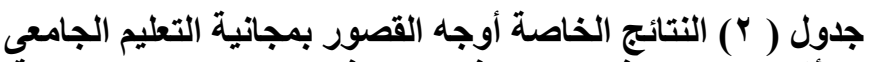

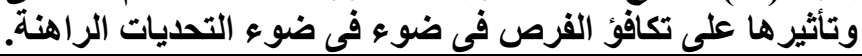

\begin{tabular}{|c|c|c|c|c|c|}
\hline الترتيب & 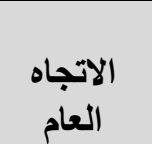 & 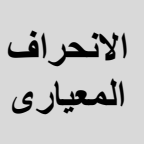 & الحسابى & العبارة & p \\
\hline$r$ & كبيرة جدا & $1 . Y \wedge V$ & $\varepsilon . \xi Y$ & قلة الاهتمام باختبارات القبول للالتحاق & 1 \\
\hline 0 & كبيرة جدا & $1 . Y 0 \varepsilon$ & $\varepsilon .4 q$ & خلل في توزيع المؤسسات التعليمية الجمهورية & r \\
\hline 7 & كبيرة & 1.21. & \&.1. & 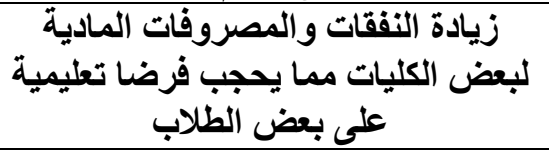 & $r$ \\
\hline$\Lambda$ & ضعيفة & $1 . \leqslant 4$ & Y.00 & الفرص التعليمية للبنات أقلّ من الفرص للبنين & $\varepsilon$ \\
\hline 1 & كبيرة جدا & $1 . Y 1$. & $\leqslant . \leqslant 0$ & الأخذ بنظام التوزيع الجغرافي للطلاب بلاب بلتات & 0 \\
\hline$r$ & كبيرة & 1.117 & $\varepsilon .41$ & ضعف التوازن في اعداد هيئات التّاتيس & 7 \\
\hline V & متوسطة & I.rYg & r.Y. & وجود قصور في الخدمات التعليمية & V \\
\hline$\varepsilon$ & كبيرة & $1.1 Y \varepsilon$ & $\varepsilon . \Gamma$ & 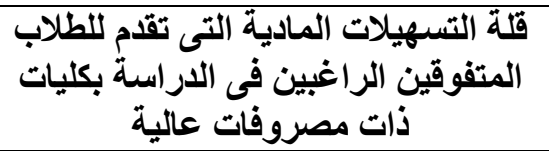 & $\wedge$ \\
\hline & كبيرة & $1 . \wedge 71$ & $r .90$ & الإجمالى & \\
\hline
\end{tabular}

ا. جاءت العبارة رقم(ه)، والتى تتص على" الأخذ بنظام التوزيع الجغرافي للطلاب المتقدمين" بلرجة كبيرة جداً في المرتبة الأولى من حيث شدة الموافقة، حيث بلغت نسبة المتوسط

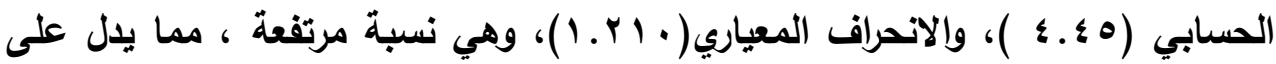
أن التوزيع الجغرافى يعتبر من أشد اوجه القصور والتى يعمل على عدم تكافؤ الفرص

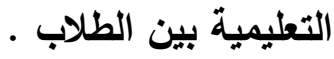

r. جاءت العبارة رقم( ) )، والتى تتص " قلة الاهتمام باختبارات القبول للالتحاق بجامعات " بلرجة كبيرة جدا في المرتبة الثانية من حيث شدة الموافقة، حيث بلغت نسبة المتوسط

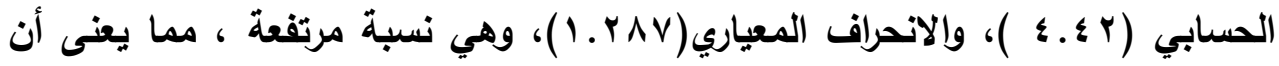
الكثير من الكليات لا تهتم باختبارات القبول للطلاب . 
Г. جاعت العبارة رقم(؟)، والتى تنص على "ضعف التوازن في اعداد هيئات التدريس

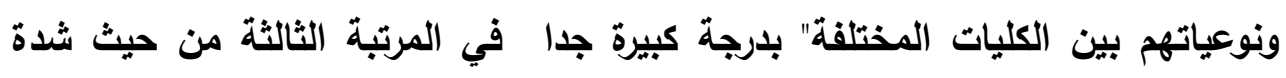

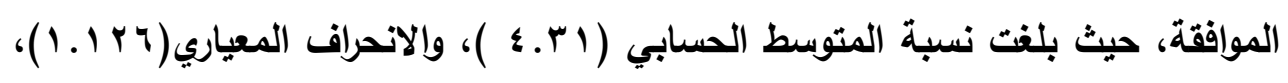
وهي نسبة مرتفعة

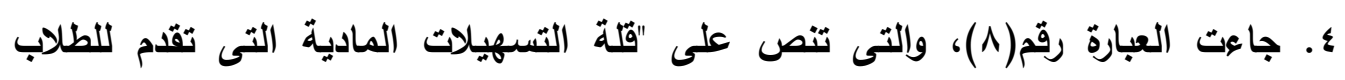

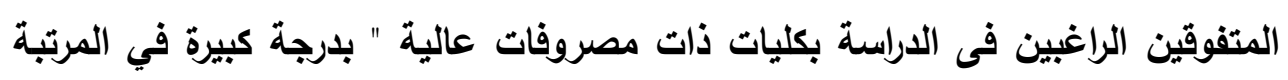

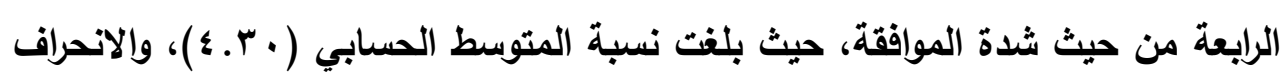

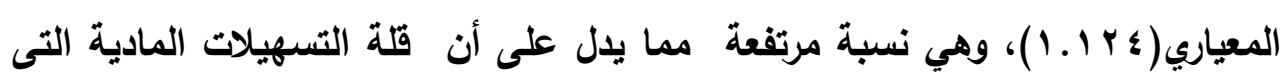

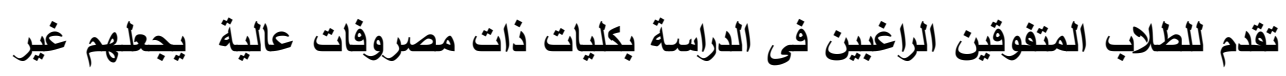

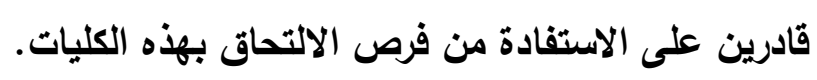

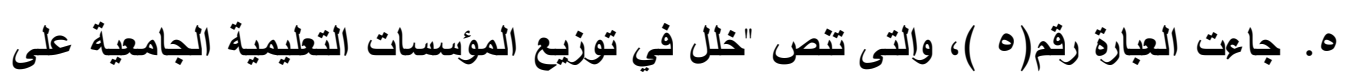

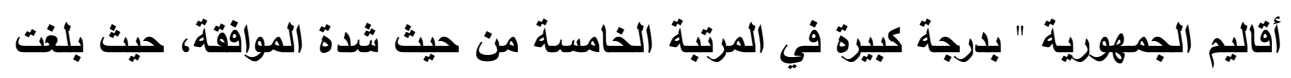

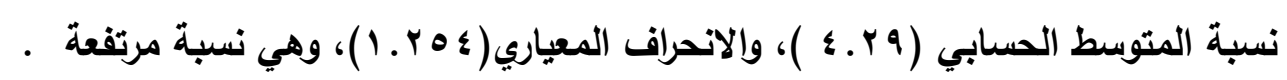

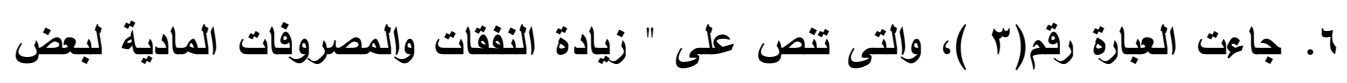

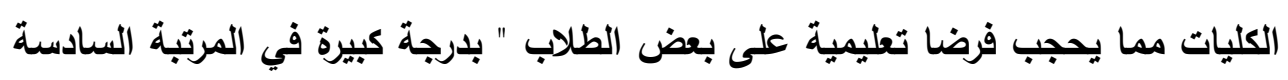

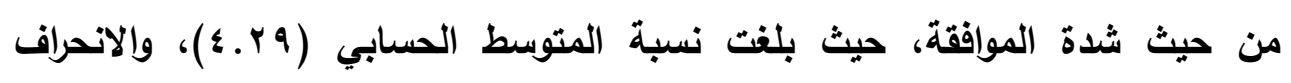

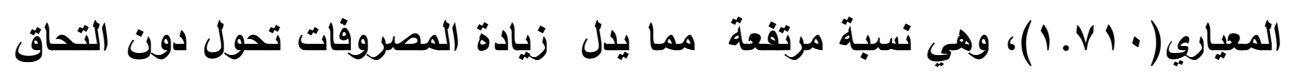

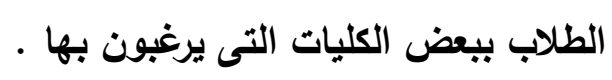

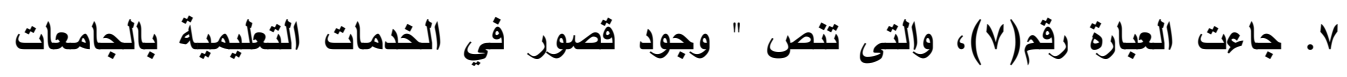

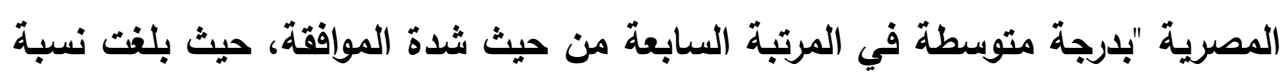

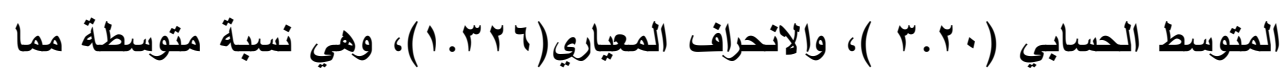

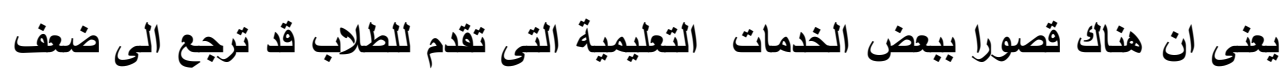

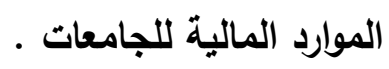
^. جاءت العبارة رقم(ء)، والتى تنص" الفرص التعات التعليمية للبنات أقل من الفرص المتاحة

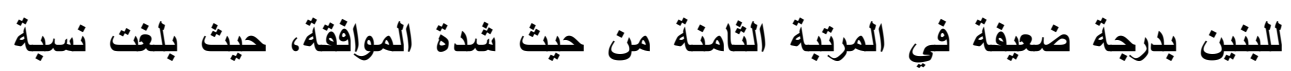




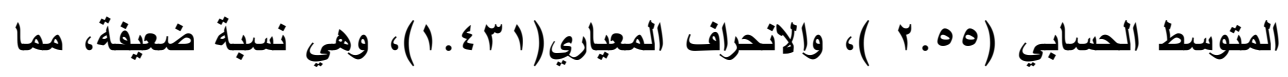

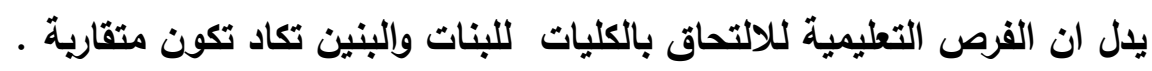

المحور الثانى : النتائج الخاصة بـالآثار المترتبة على القصور في تكافؤ الفرص بـالجامعات

: المصرية

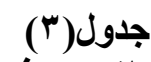

النتائج الخاصة بالآثار المترتبة على القصور في تكافؤ الفرص بالجامعات المصرية

فى ضوء فى ضوء التحديات الر الهنة

\begin{tabular}{|c|c|c|c|c|c|}
\hline الترتيب & 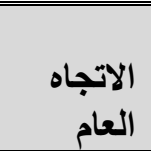 & 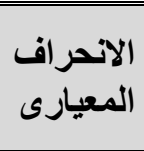 & 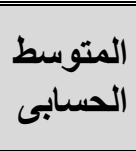 & 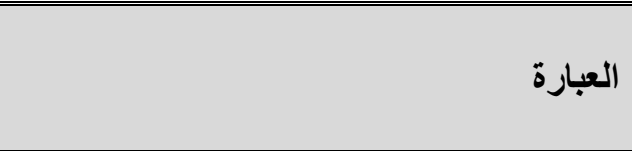 & p \\
\hline$r$ & كبيرة جدا & $1.0 \leq 1$ & $\left\{. Y_{1}\right.$ & تبن الطلاب الفوارق الطبقية و الحراك الاجتماعى & 1 \\
\hline 1 & كبيرة جدا & $1.70 r$ & $\varepsilon . \varepsilon$. & بكليات القمة لظروفهم المادية الطلاب المتفوقين & $r$ \\
\hline$r$ & كبيزة جدا & $1.1 Y \Lambda$ & $\varepsilon . \mu 1$ & تدهور قيم المساواة و العدالة الاجتماعية & $r$ \\
\hline 0 & متوسطة & 1.701 & r.ro & الصراع القيمى والاجتماعى بين طلاب الجامعة & $\varepsilon$ \\
\hline$\varepsilon$ & كبيرة & $1 . r r$ & $\varepsilon .1 \mathrm{~V}$ & ازلجواجية فى مستويات الخريجين تبعا للتوزيع & 0 \\
\hline 7 & كبيرة & $Y . \leqslant 01$ & $\varepsilon .17$ & المجتمع التوازب بين التريج فيى الكلين واحتيات النظرية & 7 \\
\hline & 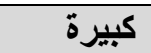 & $1 . Y 01$ & \&.1. & 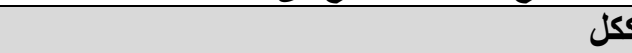 & \\
\hline
\end{tabular}

يتضح من الجدول السابق أن:

ا. جاعت العبارة رقم(ץ)، وإلتى تتص على " إهدار الكفاءات لعدم التحاق الطلاب المتفوقين

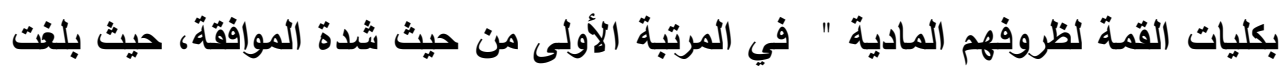

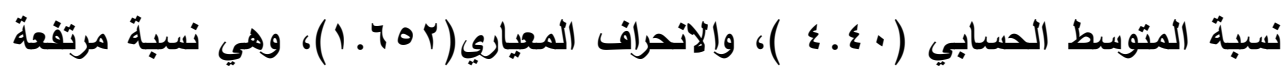
مما يدل على ان المعوقات التى تعوق التحلق المتفوقين بكليات القمة يعمل على هدر

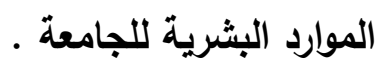

r. جاعت العبارة رقم(r)، والتى تنص على "تدهور قيم المساواة والعدالة الاجتماعية بلرجة كبيرة جداً في المرتبة الثانية من حيث شدة الموافقة، حيث بلغت نسبة المتوسط

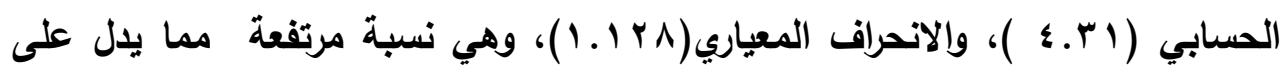

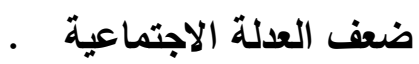


r. جاعت العبارة رقم(1)، والتى تتص على "تعميق الفوارق الطبقية والحراك الاجتماعى بين

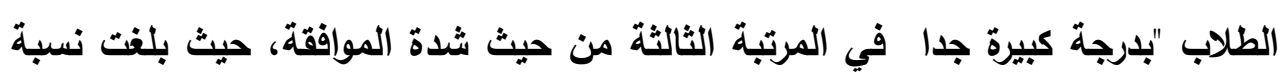

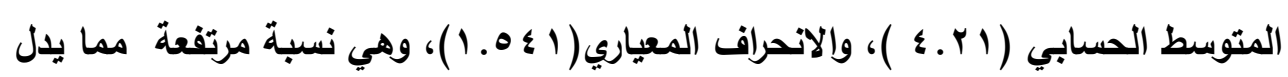
على زيادة الفجوة بين الطبقات الاجتماعية. ع. جاعت العبارة رقم(ه )، والتى تتص على " ازدواجية فى مستويات الخريجين تبعا للتوزيع الجغرافى " بدرجة كبيرة في المرتبة الرابعة من حيث شدة المواققة، حيث بلغت نسبة

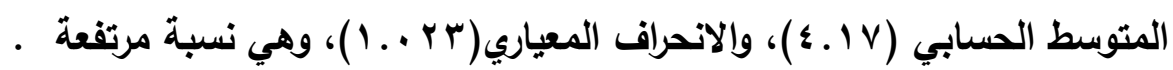
ه. جاعت العبارة رقم(ه )، والتى تتص على " ضعف التوازن بين الخريجين واحتياجات

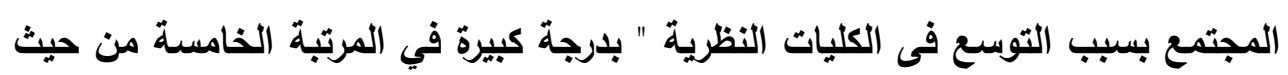

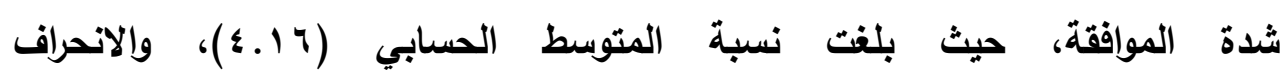

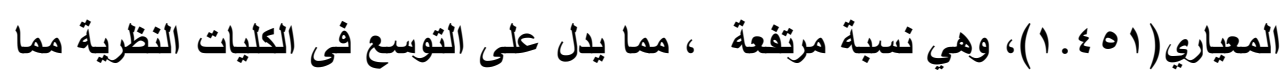
يقلل فرص التحاق الطلاب بالكليات العملية . צ. جاعت العبارة رقم( ؛ ))، والتى تنص على " الصراع القيمى والاجتماعى بين طلاب

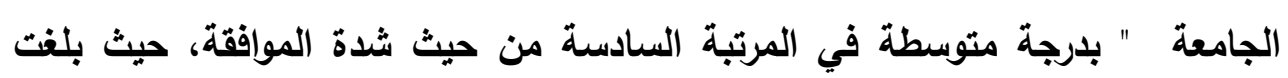

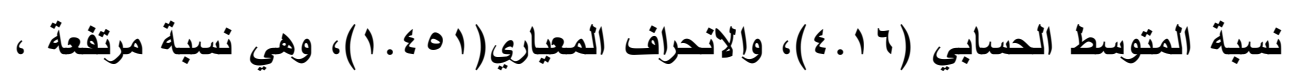
حيث أن عدم تكافؤ الفرص التعليمية يزيد من الصراع الطبقى بين الطلاب .

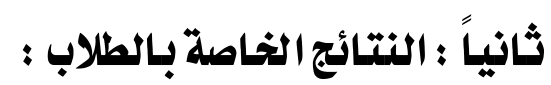

الإجابة على السوأل الأول : ما المعايير التى تم بناء عليها قبولك بكليتك؟ ما المعاييز جدول ( ) المعايير التى تم بناء عليها قبوللك بكليتك

\begin{tabular}{|c|c|c|c|}
\hline النسبة & 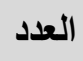 & 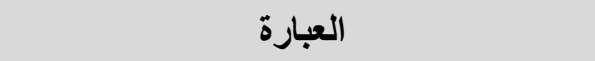 & م \\
\hline$\% \wedge \vee . \bullet$ & $0 \leqslant r$ & مجموع درجاتك فى الثانوية العامة & 1 \\
\hline$\% \leqslant 0$ & $r \wedge$ & اجتياز اختبار القدرات الخاصى بالكلية & $r$ \\
\hline$\% \vee .9$ & $\leqslant 9$ & الكلية رويت ميولك ورغبتك فى الالتحاق بهذه & $r$ \\
\hline$\% 1 \ldots$ & $T r$. & الإجمالى & \\
\hline
\end{tabular}

يتضح من الجدول السابق ما يلى : 
أن المعيار الأساسي لقبول الطلاب بهذه الجامعات هو مجموع درجات الطالب في الثانوية

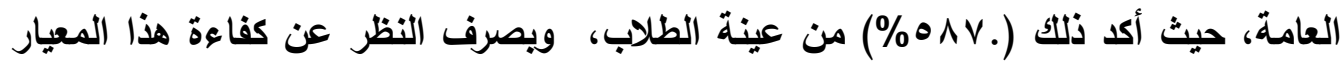
في التعبير عن المستويات الحقيقية للطلاب فإن هذا المعيار يؤخذ في الغالب بمفرده دون الأخذ في الاعتبار قدرات واستعدادات وميول الطلاب ما لا يتفق مع مبدأ تكافؤ الفرص الذي يؤكد على ضرورة مراعاة هذه القدرات والميول في شروط القبول للالتحاق بالتعليم الجامعي. الإجابة على السؤال الثانى : إذا كان لايك الرغبة في الالتحاق بكلية أخرى فما هـى الأسباب

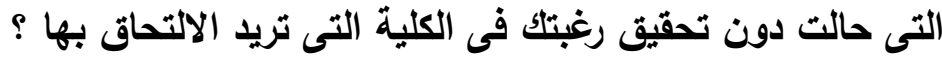

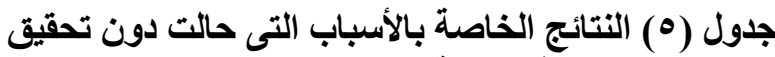

رغبتك فى الكلية التى تريد الالتحاب التى بهالت دون

\begin{tabular}{|c|c|c|c|}
\hline 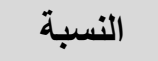 & 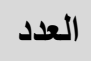 & 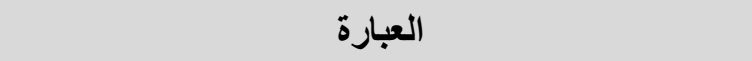 & p \\
\hline$\% Y \varepsilon . r$ & $1 \leq 9$ & 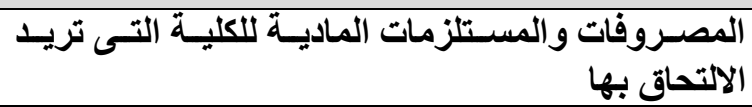 & 1 \\
\hline$\% 79.0$ & $\varepsilon r$ & مجموع درجاتك فى الثانوية العامة لا يؤهلك لذلك & $r$ \\
\hline$\%$ \%.ร & $\varepsilon$ & إلقامتلية التى ترغب الالتحاق بها تقع فى مكان بعيد عن & $r$ \\
\hline$\% 1 \ldots$ & Tr. & الإجمالى ال الإلى & \\
\hline
\end{tabular}

يتضح من الجدول السابق ما يلى :

أن السبب الرئيسى التي حال دون دخول بعض الطلاب لكليات يرغبونها كاتت مجموع درجات الثانوية العامة، حيث أكد ذلك (9.07\%) من عينة الطلاب الذين كانت لهم رغبة في دخول كليات أخرى غير كلياتهم، وهذا ما يتوافق مع النتيجة السابقة حيث إن الأخذ بنتيجة امتحان الطالب في الثهادة الثانوية كشرط أوحد في القبول في شأنه حرمان بعض الطلاب من دخول كليات يمكن أن يحققوا فيها تفوقاً، ويله " المصروفات والمستلزمات المادية للكلية

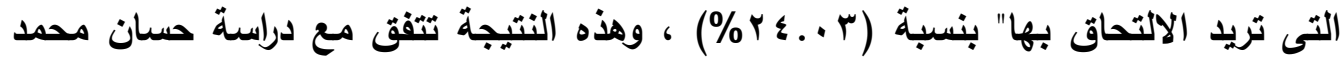

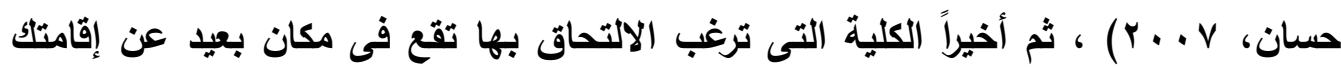

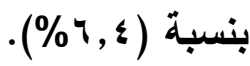


ملخص النتائج

1. أوضحت استجابات عينة أعضاء هيئة التدريس أن من نواحي القصور في تطبيق تكافؤ

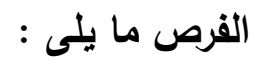

الأخذ بنظام التوزيع الجغرافي للطلاب المتقدمين، حيث بلغت نسبة المتوسط الحسابي

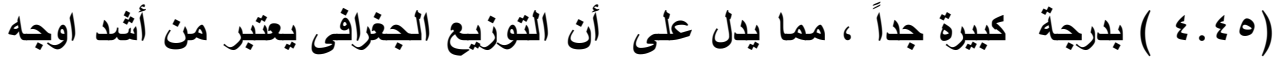

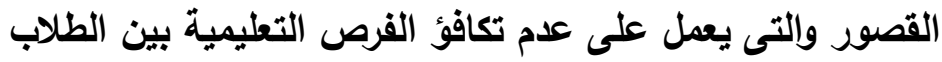

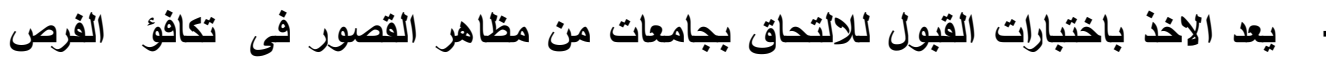

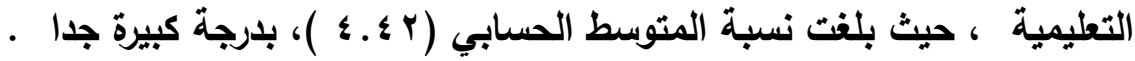

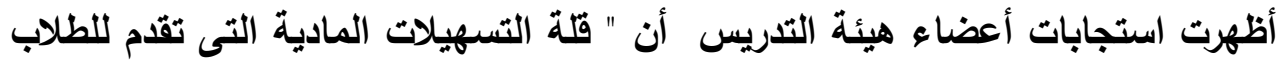
المتفوقين الراغبين فى الدراسة بكليات ذات مصروفات عالية " من مظاهر القصور

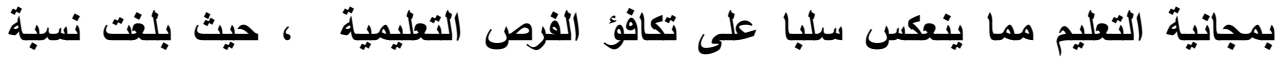
المتوسط الحسابي (· •. ؛ )، بلرجة كبيرة وهي نسبة مرتفعة. - أيدت عينة البحث أن "خلل في توزيع المؤسسات التطليمية الجامعية على أقاليم الجمهورية " من مظاهر ضعف تكافؤ الفرص للطلاب ، حيث بلغت نسبة المتوسط

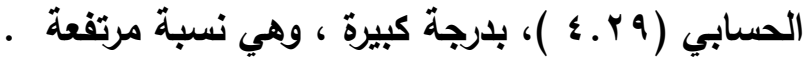
- أظهرت استجابات أعضاء هيئة التدريس أن " زيادة النفقات والمصروفات المائهة المادية

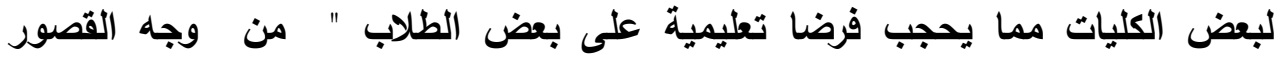

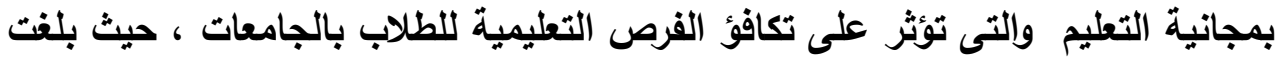

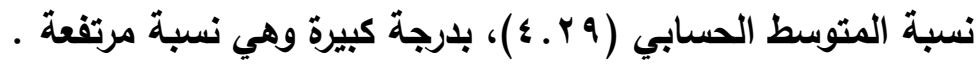
r. من الآثار المترتبة على القصور في تكافؤ الفرص بالجامعات المصرية مايلى: -

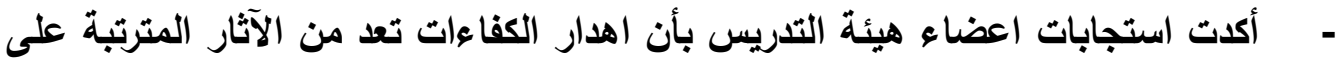

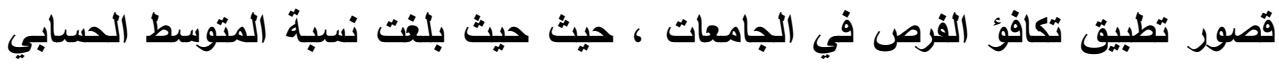

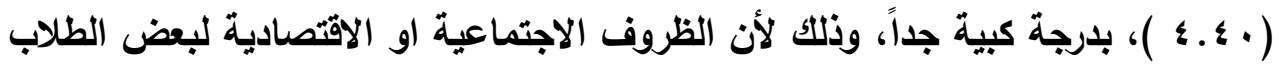
المتفوقين قد تحول دون التحاقهم بكليات يظهرون فيها نبوغهم وإمكاناتهم العقلية.

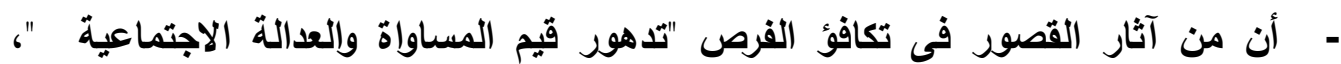

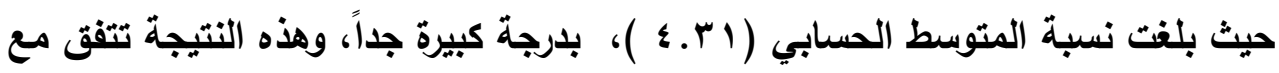


دراسة) أحمد محمد توفيق رستم ، والتى توصلت الى ان ضعف عدالة توزيع الفرص يؤى إلى تدهور قيم العدالة الاجتماعية

- أن المعيار الأساسي لقبول الطلاب بهذه الجامعات هو مجموع درجات الطالب في الثانوية

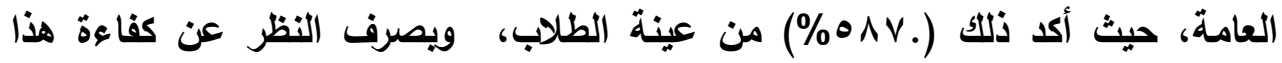
المعيار في التعبير عن المستويات الحقيقية للطلاب فإن هذا المعيار يؤخذ في الغالب بمفرده دون الأخذ في الاعتبار قدرات واستعدادات وميول الطلاب ما لا يتفق مع مبدأ تكافؤ الفرص الأي يؤكد على ضرورة مراعاة هذه القدرات والميول في شروط القبول للالتحاق بالتعليم الجامعي. - أن السبب الرئيسى التي حال دون دخول بعض الطلاب لكليات يرغبونها كانت مجموع درجات الثانوية العامة، حيث أكد ذلك (ه.97\%) من عينة الطلاب الأين كانت لهم رغبة في دخول كليات أخرى غير كلياتهم، وهذا ما يتوافق مع النتيجة السابقة حيث إن الأخذ بنتيجة امتحان الطالب في الشهادة الثانوية كشرط أوحد في القبول في شأنه حرمان بعض الطلاب من دخول كليات يمكن أن يحققوا فيها تفوقاً، ويله " المصروفات والمستلزمات المادية للكلية التى تريد الالتحاق بها" بنسبة (ب ... ب \%\%) ، ثم أخيراً الكلية التى ترغب الالتحاق بها تقع فى مكان بعيد عن إقامتك بنسبة (ع , ؟\%) r. أن المعيار الأساسي لقبول الطلاب بهذه الجامعات هو مجموع درجات الطالب في الثانوية العامة، حيث أكد ذلك (ه^.๑\%) من عينة الطلاب. ويصرف النظر عن كفاعة هذا المعيار في التعبير عن المستويات الحقيقية للطلاب فإن هذا المعيار يؤخذ في الغالب بمفرده دون الأخذ في الاعتبار قدرات واستعدادات وميول الطلاب ما لا يتفق مع مبدأ تكافؤ الفرص الذي يؤكد على ضرورة مراعاة هذه القدرات والميول في شروط القبول لكلالتحاق بالتعليم الجامعي. ؛. أن العقبة الرئيسية التي حالت دون دخول بعض الطلاب لكليات يرغبونها كاتت مجموع درجات الثانوية العامة، حيث أكل ذلك (9.9\%\%) من عينة الطلاب الأين كانت لهم رغبة في دخول كليات أخرى غير كلياتهم، وهذا ما يتوافق مع النتيجة السابقة حيث إن الأخذ بنتيجة امتحان الطالب في الشهادة الثانوية كشرط أوحد في القبول في شأنه حرمان بعض الطلاب من دخول كليات يمكن أن يحققوا فيها تفوقاً. 


\section{التوصيات المترحة :}

في ضوء ما أسفرت عنه نتائج البحث فإنه يمكن تقليم المقترحات والتوصيات التالية التي

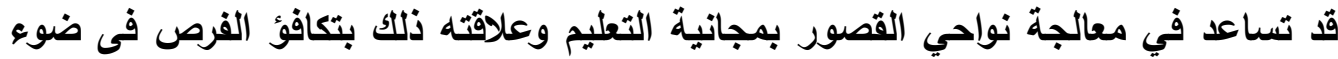

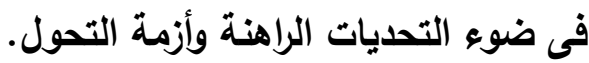

1. عدم الاقتصار على نتيجة الطلاب في امتحان الثهادة الثانوية العامة كمعيار وحيد للقبول بالجامعات، وضرورة الأخذ في الاعتبار تطبيق اختبارات ومقاييس تكثف عن الطنان

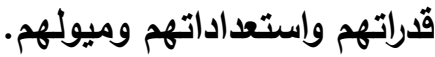
r. الاهتمام بأنظمة التوجيه والإرشاد داخل الجامعات حتى يمكن الكثف عن الخصائص العقلية والنفسية والجسمية للطلاب وتوجيههم نحو التخصصات والثنب التئي تناسب هذه الخصائص. r. التوسع في إنشاء التخصصات والثعب بالكليات لمقابلة الاحتياجات التعليمية للطلاب وزيادة عدد الفرص أمامهم. ؛. إعادة النظر في نظم الدراسة الجامعية بحيث تتيح للطلاب فرصاً أكبر للاختيار بين

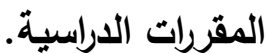
ه. الأخذ بالنظم الجامعية الأخرى مثل الجامعة المفتوحة وجامعات الهواء وذلك حتى تتاح الفرص لمن تحول ظروفهم التقيد بقوانين التعليم النظامية.

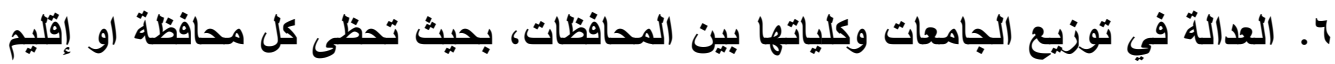
بالعدد الذي يتناسب مع امتدادها الجغرافي وكثافتها السكانية.

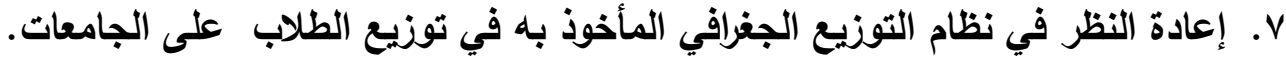

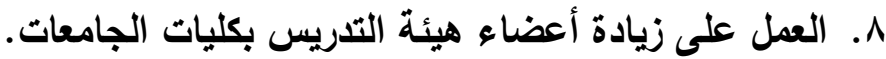
9. رفع مستوى الذدمات التعليمية بالجامعات من أساتذة ومباني وتجهيزات وخدمات مكتبية ويحثية

ـ 1 ـ إنشاء كليات في جامعات الصعيد تناظر الكليات المنفردة بها جامعات أخرى 11 ا. الاهتمام بالطلاب المتفوقين وتقديم التسهيلات المادية التي تساعدهم في مواصلة دراستهر

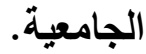
r r ا.تدبير المعونات المادية ووسائل الرعاية الاجتماعية المختلفة للطلبة الذين تعجزهم أحوالهم

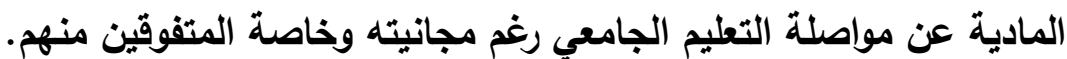




\section{المراجع}

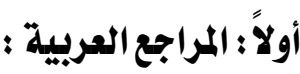

ا. أحمد إبراهيم أحمد. التربية المقارنة ونظم التعليم، الإسكندرية، دار الوفاء لانيا الطباعة

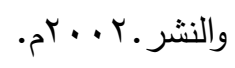

r. أحمد إبراهيم أحمد. التربية المقارنة ونظم التعليم. الإنكندرية. دار الوفاء لدنيا الطباعة والنشر،

$$
\text { . }
$$

r. أحمد محمد توفيق رستم ـ "دراسة ددى عدالة توزيع الفرص التعليمية في التعليم العام قبل الجامعي

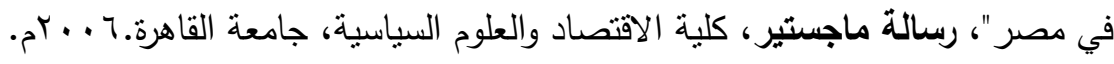

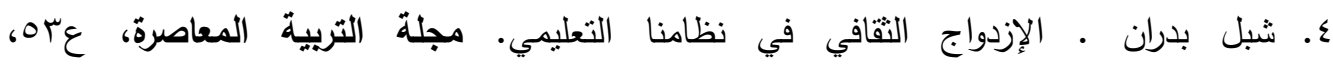

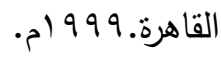
ه. جمال علي الدهان • "روية مقترحة لنطوير نظم القبول بالجامعات المصرية الحكومية لتحقيق

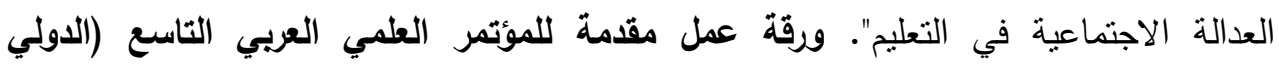

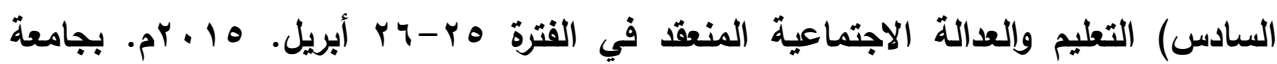
سوهاج. مجلة الثقافة والتتمية. س(10). T. حامدعمار. الإصلاح المجتمعي: إضاءات قثتافية واقتضاءات تربوية، القاهرة: الهيئة الدصرية

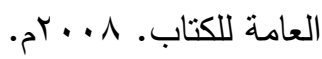
V. حسان محد حسان. "رأي في إلغاء مجانية التعليم". التربية المعاصرة.ع(ه). القاهرة: رابطة التربية

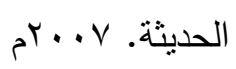

^. حسن سلامة الفقي."تكافؤ الفرص التعليمية ومجتمع الجدارة". مجلة العوم الاجتماعية، مج( (').

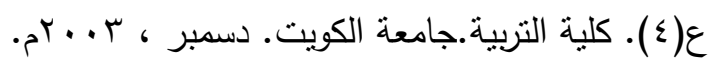

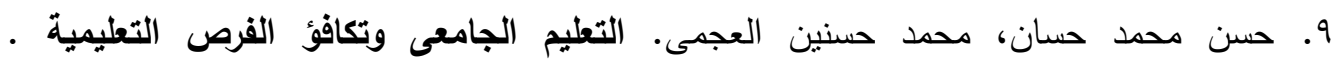

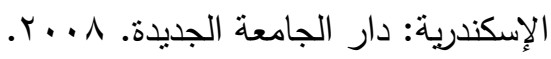

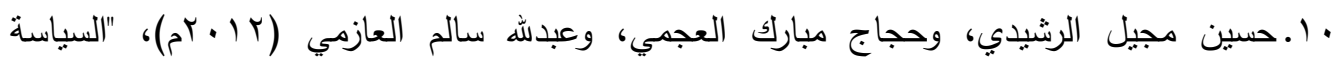

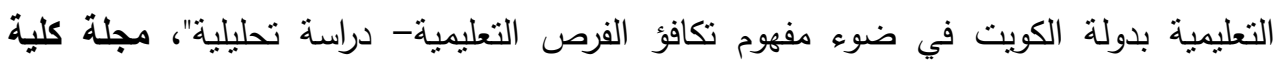

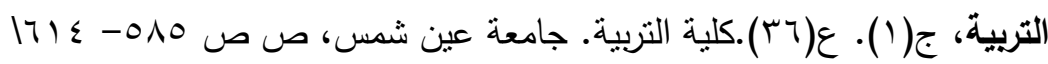

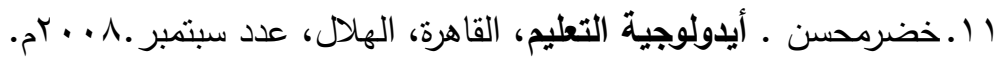
r ا.سعيد إسماعيل علي. "الأبعاد الاجتماعية لقضية ترثيد مجانية التعليم الجامعي". أبحاث مؤتمر

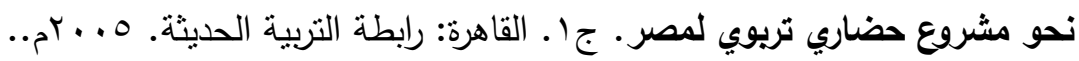


س ا ـسها عوض محمد السيد الفقي • "الدور التعليم الجامعي المفتوح في تحقيق تكافؤ الفرص التعليمية

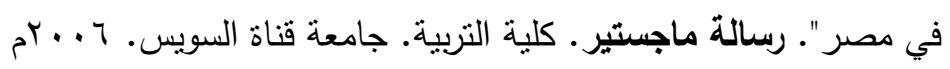

ع ا ـ سهير محمد حوالة ـ "السياسة التعليمية بالمملكة العربية السعودية في ضوء مفهوم تكافؤ الفرص التعليمية، دراسة تحليلية"، مجلة العلوم التربوية.مج(0 1). ع(ع). معهد الدراسات والبحوث

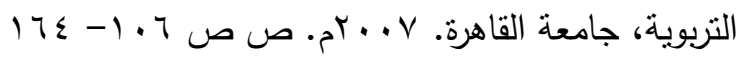

1ا.شيماء جبر عبدلله الحبشي • "التعليم الأجنبي في مصر وتكافؤ الفرص التعليمية". رسالة

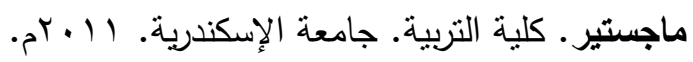

7 ا ـ عبدالرحمن بن محمد بن علي الحبيب: دور كليات المجتمع في تحقيق تكافؤ الفرص التعليمية،

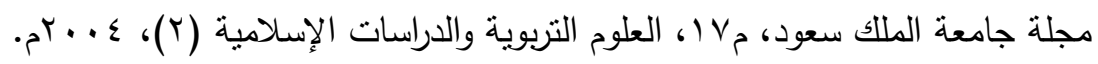

V ا ـلي الثخيبي • علم اجتماع التربية المعاصر تطوره- منهجيته- تكافؤ الفرص التعليمية. القاهرة:

$$
\text { دار الفكر العربي. } 9 \text { • . ب م. }
$$

1 ا ـ علي عبدالعزيز علي • "دراسة تقويمية لبعض المدارس التجريبية في ضوء مفهوم تكافؤ الفرص التعليمية". رسالة دكتوراه. كلية التربية. جامعة المنوفية، 10 ـ برم.

9 ( ـ عماد صيام. سياسات القبول بين العدالة ومشكلات التتمية ـ مؤتمر التعليم العالى فى مصر خريطة الواقع واستشراق المستقبل ، ع(V) ). القاهرة .

• r. عمرو محمد حامد عيسى . "دعم تكافؤ الفرص التعليمية ودوره في إصلاح التعليم الأساسي في مصر ". رسالة دكتوراه. كلية التربية. جامعة دمياط، ب ا ـ بم. ا ا. عمرو محمد حامد عيسى ."دعم تكافؤ الفرص التعليمية ودوره في إصلاح التعليم الأساسي في

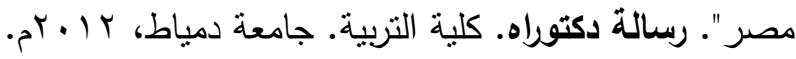
Y r.فرجاني، نادر • التعليم العالي والعولمة : منظور مصري. مؤتمر الجامعة القاهرة: "التعليم العالي في مصر: خريطة الواقع واستشراف المستقبل" ، خلال الفترة من ع I V Vبراير. القاهرة.

$$
.0
$$

سץ.فؤاد أبو حطب، أمال صادق، مناهج البحث وطرق التحليل الإحصائى فى العلوم الإنسانية

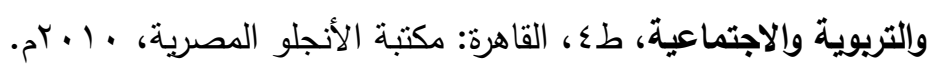

ـ ـ. ماري، ج.ر.ف. قبول الطلاب الراشدين في جامعة دار السلام، ترجمة: محمود عبدالحليم السيد.

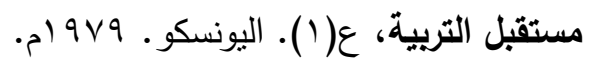

ه . مجدي عزيز إبراهيم. تطوير التعليم في عصر العولمة. القاهرة: مكتبة الأنجلو المصرية. . . . rم. צr. محسن خضر • أيدولوجية التعليم، القاهرة: الهلال، عدد سبتمبر .V • . rم. من فجوات العدالة في التعليم. القاهرة: الدار المصرية اللبنانية، . . . بم. .$r V$ 
^ץ.محمد النصر حسن محمد ."تطور تحقيق العدالة الاجتماعية في سياسة التعليم المصري منذ ثورة

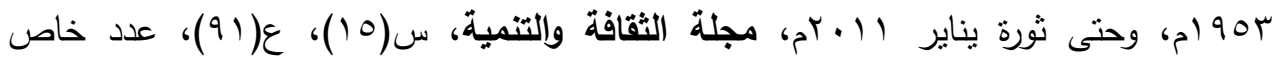

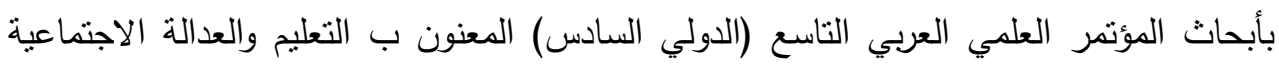

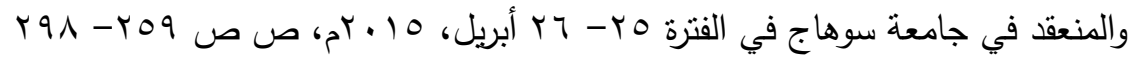

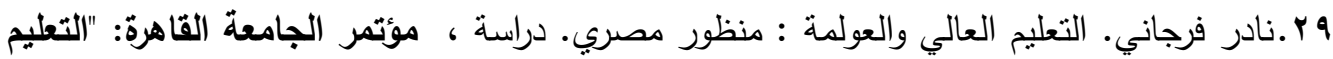

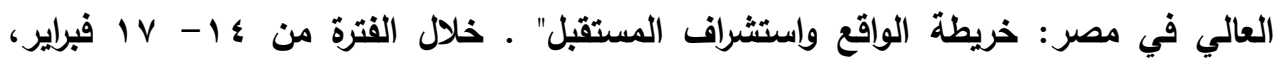
$.0 \mathrm{p} \cdot 10$

• r. هانم خالد محمد سليم. "تصور مستقبلي دور التعليم الإلكتروني في تحقيق تكافؤ الفرص التعلييمة

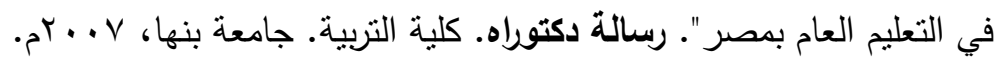

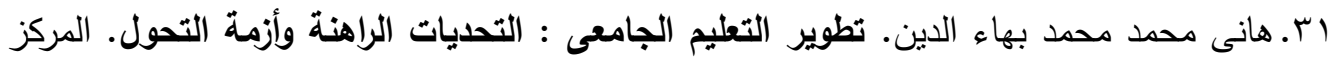

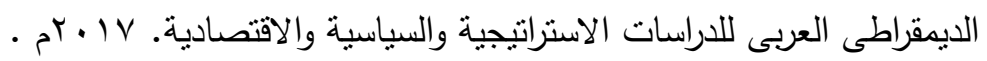

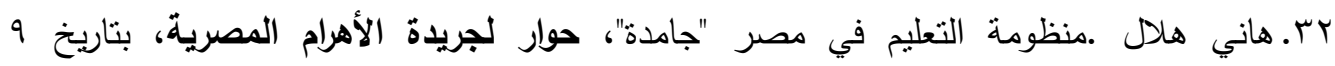

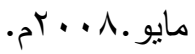

ثانياً : المراجع الأجنبية : مانية

(1) .Brubachr, J On the Philosophy of Higher Education, (San Fransisco,Jessy-Bass Pub,2012.

(2) Knoeppel, R. \& Brewer, C. "Education Reform, Equal Opportunity and Eductional Achievement: Do Trend Data Adequately Report Pro-gress?" Education Policy Analysis, Vol. 19, No. 10,2011, pp. 1-31.

(3) Noel, B, "Education Reform In Latin America: Equal Educational opportunity?", Gist Education and learning Journal, Vol. 3, ,2015PP. 134-- 157 
مجانية التعليم الجامعى وعلاقتها بتكافؤ الفرص التعليمية فى ضوء التحديات الراهنة وأزمة التحول.

$$
\text { ملحق (1) استبيان }
$$

استطلاع رأى أعضاء هيئة التدريس حول مجانية التعليم الجامعى وعلاقتها بتكافؤ الفرص التعليمية فى ضوء التحديات الراهنة وأزئمة الجامع التحول

\begin{tabular}{|c|c|c|c|c|c|c|}
\hline \multicolumn{5}{|c|}{ درجة المو افقة } & \multirow{2}{*}{ 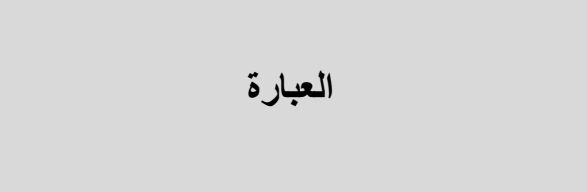 } & \multirow[b]{2}{*}{ r } \\
\hline ضديفة & ضعيفة & متوسطة & كبيرة & كبيرة & & \\
\hline \multicolumn{7}{|c|}{ أولاً: أوجه القصوربمجانية التعليم الجامعى وعلاقتها بتكافؤ الفرص } \\
\hline & & & & & قجامعات الاتمـــام باختبـار ات القبـول للالتحـــاق & 1 \\
\hline & & & & & 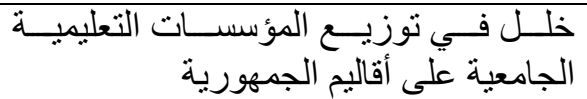 & r \\
\hline & & & & & 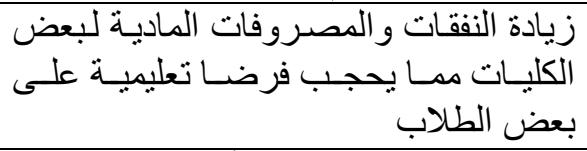 & r \\
\hline & & & & & الفتاحة للبنين التعليميـة للبنـات أقلـ مـن الفـرص & $\varepsilon$ \\
\hline & & & & & 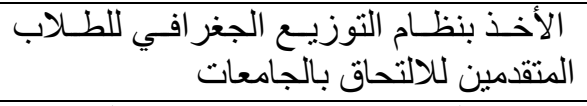 & 0 \\
\hline & & & & & ونوعياتهم بين الكليات المختلفة فيئات التدريس & 7 \\
\hline & & & & & 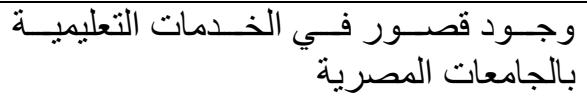 & $\checkmark$ \\
\hline & & & & & 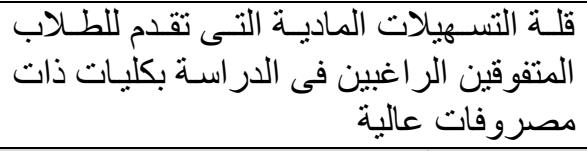 & $\wedge$ \\
\hline \multicolumn{7}{|c|}{ ثانياً:الآثار المترتبة على القصور في تكافؤ الفرص بالجامعات المصري } \\
\hline & & & & & تين الطعلاب الفوارق الطبقية و الحر الك الاجتمـاعى & 1 \\
\hline & & & & & 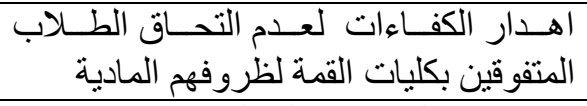 & $r$ \\
\hline & & & & & تدهور قيم المساو اة و العدالة الاجتماعية & $r$ \\
\hline & & & & & الجامعة اع القيمـى و الاجتمــــى بـين طـلاب & $\varepsilon$ \\
\hline & & & & & 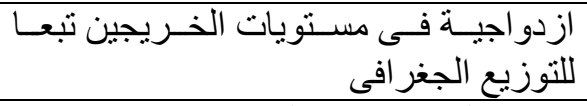 & 0 \\
\hline & & & & & 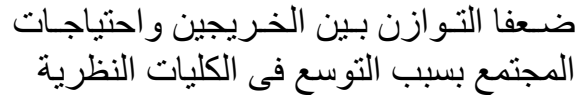 & 7 \\
\hline
\end{tabular}

ملدق (r) استبيان للطلاب حول 
مجانية التعليم الجامعى وعلاقتها بتكافؤ الفرص التعليمية فى ضوء التحديات الراهنة وأزمة التحول.

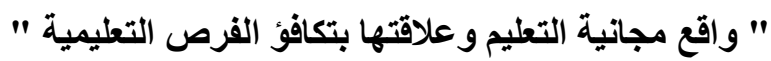

أولا : ما المعاييرالتى تم بناء عليها قبولك بكليتك؟

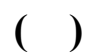

( )

( )

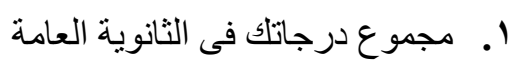
r. اجتباز اختبار القدرات الخاصى بالكلية r. روعيت ميوللك ور غبتلك فى الالتحاق بهذه الكلية

ثانياً: إذا كان لايك الرغبة فى الالتحاق كلية أخرى فما هى الأسباب التى حالت دون تحقيق رغبتك فى

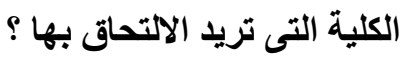

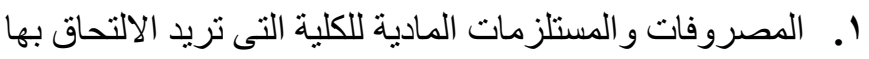
r. . مجموع درجاتك فى الثانوية العامة لا يؤ هلك لذلك r. الكلية التى تر غب الالتحاق بها تقع فى مكان بعيد عن إقامتلك 